Cite this: Metallomics, 2014, 6, 1254

Received 20th February 2014, Accepted 21st May 2014

DOI: $10.1039 / c 4 m t 00048 j$

www.rsc.org/metallomics

\title{
Identification of major zinc-binding proteins from a marine cyanobacterium: insight into metal uptake in oligotrophic environments $\dagger$
}

\author{
James Paul Barnett, ${ }^{a}$ David John Scanlan ${ }^{b}$ and Claudia Andrea Blindauer*a
}

\begin{abstract}
Marine cyanobacteria make a significant contribution to primary production whilst occupying some of the most nutrient poor regions of the world's oceans. The low bioavailability of trace metals can limit the growth of phytoplankton in ocean waters, but only scarce data are available on the requirements of marine microbes for zinc. Recent genome mining studies suggest that marine cyanobacteria have both uptake systems for zinc and proteins that utilize zinc as a cofactor. In this study, the oligotrophic strain Synechococcus sp. WH8102 was grown at different zinc concentrations. Using metalloproteomics approaches, we demonstrate that even though this organism's growth was not affected by extremely low zinc levels, cells accumulated significant quantities of zinc, which was shown to be proteinassociated by 2D liquid chromatography and ICP-MS. This indicates that the mechanisms for zinc uptake in Synechococcus sp. WH8102 are extremely efficient. Significantly, expression of SYNW2224, a putative porin, was up-regulated during growth in zinc-depleted conditions. Furthermore, along with 30 other proteins, SYNW2224 was captured by immobilised zinc affinity chromatography, indicating the presence of surface-exposed site(s) with metal-binding capacity. It is proposed that this porin plays a role in high-affinity zinc uptake in this and other cyanobacteria.
\end{abstract}

\section{Introduction}

Zinc is an important micronutrient required by almost all living organisms, functioning as a catalytic cofactor in enzymes and as a structural component of numerous proteins. ${ }^{1}$ Recent bioinformatic studies suggest that up to $15 \%$ of all proteins in a given genome contain $\mathrm{Zn}^{2+}$.,3 Although prokaryotes have lower requirements for zinc than eukaryotes, zinc is thought to be essential for bacteria, too, and bacterial proteomes are predicted to include 5-6\% zinc-binding proteins. ${ }^{2}$ However, these bioinformatic predictions are ultimately based on limited experimental biochemical and bio-inorganic data, and it has been concluded that "microbial metalloproteomes are largely uncharacterised". "The genomes of many organisms encode large numbers of uncharacterised conserved hypothetical proteins, some of which may contain novel metal binding sites. ${ }^{5,6}$ Even in cases where homologous proteins are known and permit structural modelling, it is often not possible to reliably

\footnotetext{
${ }^{a}$ Department of Chemistry, University of Warwick, Coventry, CV4 7AL, UK. E-mail: c.blindauer@warwick.ac.uk; Fax: +44 (0)24 76 524112; Tel: $+44(0) 2476528264$

${ }^{b}$ School of Life Sciences, University of Warwick, Coventry, CV4 7AL, UK $\dagger$ Electronic supplementary information (ESI) available. See DOI: 10.1039/ c4mt00048j
}

predict the metal specificity of a particular protein. A further complication is introduced by "cambialistic" proteins, ${ }^{7}$ which may utilise different metal cofactors in different species or circumstances. These problems may be particularly pronounced in the case of organisms that live in extreme environments. One such extreme environment is the open ocean, one of the most nutrient-poor habitats on earth.

Whilst there is ample evidence that the bioavailability of iron can limit phytoplankton growth ${ }^{8}$ and primary production in some open ocean regions, ${ }^{9}$ the impact of zinc is less clear. ${ }^{10}$ Only picomolar concentrations of free $\mathrm{Zn}^{2+}$ occur in surface waters of the world's oceans, ${ }^{11-13}$ with the vast majority of $\mathrm{Zn}^{2+}$ found complexed to organic ligands of unknown origin and identity. ${ }^{12,14,15}$ These free $\mathrm{Zn}^{2+}$ concentrations may be sufficiently low to directly limit the growth of some phytoplankton including diatoms, coccolithophores, and green algae. ${ }^{13,16-19}$ Based on the observation of zinc/carbon co-limitation in certain eukaryotic marine phytoplankton, ${ }^{20}$ a "zinc hypothesis" has been proposed, in analogy to Martin's “iron hypothesis". ${ }^{21}$ This theory entails that on a global scale, high zinc levels in the oceans lead to increased $\mathrm{CO}_{2}$ sequestration - in turn, scarcity of zinc increases atmospheric $\mathrm{CO}_{2}$ levels.

Marine cyanobacteria are the predominant photosynthetic organisms in large parts of the oligotrophic regions of the world's oceans. ${ }^{22}$ Unfortunately, the specific requirements of 
marine cyanobacteria for zinc are scarcely studied, ${ }^{23-25}$ whereas for some freshwater cyanobacteria effects of zinc toxicity and deprivation have been examined in some detail. ${ }^{26,27}$ The genomes of over 30 marine cyanobacterial strains have been sequenced, and our genome mining work has discovered not only genes for several enzymes predicted to require a zinc cofactor, including alkaline phosphatase and one or more carbonic anhydrases, but also for proteins with likely roles in zinc uptake and trafficking; including putative periplasmic zinc binding proteins ( $\mathrm{ZnuA}){ }^{28-30}$ All strains inspected also harboured a gene for the zinc uptake regulator Zur, with recognition sites for this zinc sensor protein predicted to occur in the upstream regions of several relevant genes. Whilst these bioinformatic studies strongly point towards dedicated networks for zinc uptake and utilisation, an absolute requirement of marine cyanobacteria for zinc has not been demonstrated conclusively.

In the present study we have used the oligotrophic open-ocean strain Synechococcus sp. WH8102 $2^{31}$ as a model cyanobacterium to study its growth and cellular zinc quota under zinc-depletion conditions, and to probe the presence of major $\mathrm{Zn}^{2+}$-binding proteins using solution-state metalloproteomics approaches. Metalloproteomics, a sub-discipline of metallomics, is dedicated to the provision of experimental evidence for metal-protein interactions. ${ }^{32-36}$ Combinations of inorganic and molecular mass-spectrometry are particularly powerful approaches, whilst separation techniques have posed the major experimental challenges. ${ }^{5}$

Previously, we examined the applicability of different liquidchromatography-based approaches to probe the $\mathrm{Fe}-$, $\mathrm{Ni}-$, and Co-related proteome of Synechococcus sp. WH8102. ${ }^{5,37}$ In the present study, immobilised zinc affinity chromatography $\left(\mathrm{Zn}^{2+}\right.$ IMAC) has enabled the capture and detection of several proteins with potential functions in zinc metabolism. Besides the detection of a predicted periplasmic zinc-binding protein (ZnuA) along with several other periplasmic binding proteins, the most significant finding concerns a predicted porin, a novel candidate for mediating zinc uptake across the outer membrane of marine cyanobacteria.

\section{Materials and methods}

\section{Suppliers of chemicals and reagents}

All chemicals used were of the highest grade available and were purchased from either Fisher Scientific (UK) or Sigma-Aldrich (UK) unless otherwise indicated.

\section{Bacterial strains and growth conditions}

Axenic cultures of Synechococcus sp. WH8102 were grown in an artificial seawater medium based on Aquil, ${ }^{38,39}$ prepared using ultrapure (MilliQ $18 \mathrm{M} \Omega \mathrm{cm}^{-1}$ ) water (Table S1, ESI $\dagger$ ). The base medium (macronutrients) was Chelex-treated and then autoclaved. Micronutrient components were filter-sterilised before adding to the base medium. Media bottles and culture flasks were washed with $5 \%$ trace metal clean $\mathrm{HCl}$ prepared in house by sub-boiling point distillation and rinsed with MilliQ water before use.

The theoretical free $\mathrm{Zn}^{2+}$ concentration in the growth medium at pH 8.0 was calculated from the total EDTA and $\mathrm{Zn}^{2+}$ concentrations using the "Species" module within the IUPAC stability constants database (Data version 4.56, L.D. Pettit, Academic Software, UK), taking also into account the concentrations of other metal ions. Stability constants and $\mathrm{p} K_{\mathrm{a}}$ values were also extracted from this database.

Stocks of Synechococcus sp. WH8102 were maintained through sub-culturing in the different $\mathrm{Zn}$ media that were tested, over a long period of time. Cells were initially transferred from standard medium to zinc-depleted medium by collecting cells by centrifugation, gently washing and resuspending into the zinc-depleted medium. Before the growth measurements were carried out, cells were acclimated over several serial transfers across at least 12 weeks into fresh medium with either no zinc or $80 \mathrm{nM}$ added zinc. Cultures were grown at $25{ }^{\circ} \mathrm{C}$ with continuous illumination at $10 \mu \mathrm{E} \mathrm{m}^{-2} \mathrm{~s}^{-1}$ and shaken at $150 \mathrm{rpm}$. This light level corresponds to levels found at the bottom of the surface mixed layer, a region where clade III Synechococcus genotypes (of which Synechococcus sp. WH8102 is a member) proliferate. Such a light level also assists in stable culture maintenance, without inducing photodamage. Growth was monitored by measuring the optical density at $750 \mathrm{~nm}$ or by flow cytometry using a FACScan flow cytometer (Becton Dickinson, NJ, USA). Cultures were checked at regular intervals for contamination with other microorganisms by plating onto Aquil-Agar plates containing $500 \mathrm{mg} \mathrm{l}^{-1}$ yeast extract. Cells were harvested by centrifugation at $6000 \times g$. All growth and subsequent separation experiments were carried out in duplicate.

\section{Preparation of whole cell lysates}

Cell pellets were re-suspended in 1-10 $\mathrm{ml}$ of $10 \mathrm{mM}$ HEPES $\mathrm{pH}$ 7.2, $0.5 \%(\mathrm{w} / \mathrm{v})$ octyl $\beta$-D-glucopyranoside, with a dissolved Complete ${ }^{\mathrm{TM}}$ EDTA-free protease inhibitor cocktail tablet (Roche, UK). Cells were broken by sonication and debris was removed by centrifugation at $12000 \times g$. The BCA method ${ }^{40}$ was used to determine the total protein content of cell lysates.

\section{Preparation of soluble and insoluble cell fractions}

Cell pellets were re-suspended in $8 \mathrm{ml}$ of $20 \mathrm{mM}$ HEPES pH 7.2 containing a dissolved Complete ${ }^{\mathrm{TM}}$ EDTA-free protease inhibitor cocktail tablet (Roche, UK), and broken by sonication. Unbroken cells were removed by centrifugation at $6000 \times g$. The soluble and insoluble fractions were separated by ultracentrifugation at $200000 \times g$ for 30 minutes using a Beckman TLA100.3 rotor. The supernatant (soluble fraction) was collected, and the pellet (insoluble fraction) was re-suspended in $1 \mathrm{ml}$ of $20 \mathrm{mM}$ HEPES $\mathrm{pH} 7.2,0.5 \%(\mathrm{w} / \mathrm{v})$ octyl $\beta$-D-glucopyranoside to solubilise membrane proteins. The prepared fractions were further clarified by filtration using $0.2 \mu \mathrm{m}$ pore-sized filters.

\section{Preparation of a carboxysome enriched fraction}

Carboxysomes were prepared according to the method described by Gonzales et al., ${ }^{41}$ with some minor modifications. Briefly, cell pellets were resuspended in $3 \mathrm{ml}$ of $20 \mathrm{mM}$ HEPES $\mathrm{pH} 7.2$ containing a Complete ${ }^{\mathrm{TM}}$ EDTA-free protease inhibitor cocktail tablet. Cells were disrupted by sonication and cell debris was removed by centrifugation at $12000 \times g$ for 10 minutes. 
The collected supernatant was centrifuged at $40000 \times g$ at $4{ }^{\circ} \mathrm{C}$ for 30 minutes using a Beckman TLA100.3 rotor. The dark green pellet was resuspended in $3 \mathrm{ml}$ of $20 \mathrm{mM}$ HEPES pH 7.2, $20 \mathrm{mM} \mathrm{MgSO}, 2 \%(\mathrm{v} / \mathrm{v})$ Triton X-100 and incubated on ice for 45 minutes with occasional agitation. This step solubilises membrane lipids, whilst promoting carboxysome aggregation. The sample was centrifuged again at $40000 \times g$ to generate a yellow-brown carboxysome enriched pellet that was resuspended in $20 \mathrm{mM}$ HEPES pH 7.2.

\section{Inductively coupled plasma mass spectrometry (ICP-MS)}

$3 \%(\mathrm{v} / \mathrm{v})$ trace metal grade nitric acid purified in house by subboiling point distillation was used as the sample matrix. For quantitation, calibration was performed in the range $0-500 \mathrm{ppb}$ using external Zn and P ICP-MS standards. Er (Agilent Technologies, USA) was used as an internal standard. Measurements were taken using an Agilent 7500 series ICP mass spectrometer (Agilent Technologies, USA), equipped with a cross flow nebulizer, quartz spray chamber, and an Octopole Reaction System $\left(\right.$ ORS $\left.^{\circledR}\right)$ cell. All samples were measured in triplicate in helium gas-mode to remove matrix interferences. Cell lysates were prepared as described below from the combined cell pellets of 3 replicate cultures, and were diluted 1:20 in matrix for analysis.

\section{Two-dimensional liquid chromatography (2D-LC)}

Two-dimensional liquid chromatography (2D-LC) was performed essentially as described previously. ${ }^{37} 5 \mathrm{mg}$ total protein from the soluble, insoluble, or carboxysome enriched cell fraction was applied to a Biosep S2000 HPLC gel filtration column (Phenomenex, UK) equilibrated in $10 \mathrm{mM}$ HEPES pH 7.2 (containing $0.01 \%(\mathrm{w} / \mathrm{v}$ ) octyl $\beta$-D-glucopyranoside for the insoluble fraction). Protein was eluted isocratically in the same buffer using a flow rate of $1 \mathrm{ml} \mathrm{min}^{-1}$ and collected in $1.0 \mathrm{ml}$ fractions. The column was calibrated using $1 \mathrm{mg} \mathrm{ml} \mathrm{m}^{-1}$ solutions of bovine serum albumin - $66 \mathrm{kDa}$, Carbonic anhydrase - $29 \mathrm{kDa}$, lysozyme - $14 \mathrm{kDa}$, and substance P - $1 \mathrm{kDa}$ standards in column buffer. Dextran blue dye (GE Healthcare, UK) was used to determine the void volume $\left(V_{0}\right)$, which was $5.1 \mathrm{ml}$. Protein containing fractions $(5-13 \mathrm{ml})$ from 4 separate column runs (except for the carboxysome enriched cell fraction where just 1 column run was performed) were combined and further separated using strong anion exchange mini-spin columns (Thermo Scientific, UK). The spin columns were equilibrated using $2 \mathrm{mM}$ HEPES pH 7.2 (plus $0.01 \%$ (w/v) octyl $\beta$-Dglucopyranoside for the insoluble fraction). Protein was eluted using a $\mathrm{NaCl}$ gradient of $0-2 \mathrm{M}$ in $80 \mu \mathrm{l}$ fractions. $50 \mu \mathrm{l}$ of these samples were used for ICP-MS analysis and $30 \mu \mathrm{l}$ were retained for analysis by SDS-PAGE and peptide mass fingerprinting. All stock solutions were prepared using $18 \mathrm{M} \Omega$ water and treated with Chelex-100 resin (Bio-Rad, UK) to remove traces of contaminating metal ions. Acid-washed plastic-ware was used throughout to prevent contamination of samples with external sources of zinc or other metals. For the 2D-LC experiments for soluble and insoluble fractions, two biological replicates were carried out, with reproducible results.

\section{Immobilized metal affinity chromatography (IMAC)}

$1 \mathrm{ml}$ IMAC columns (GE Healthcare, UK) were prepared according to the manufacturer's instructions and either charged with $\mathrm{Zn}^{2+}$ or left un-charged. Columns were equilibrated with $10 \mathrm{mM}$ HEPES pH 7.2, $0.5 \mathrm{M} \mathrm{NaCl}, 0.01 \%$ (w/v) octyl $\beta$-D-glucopyranoside. $20 \mathrm{mg}$ of protein from crude cell lysates were loaded onto each column and the flow-through (FT) fraction collected. Unbound protein was washed through the column using $4 \times 1 \mathrm{ml}$ of buffer containing $2 \mathrm{mM}$ imidazole (W1-W4), before bound proteins were eluted using $2 \times 1 \mathrm{ml}$ of buffer with $20 \mathrm{mM}$ imidazole (E1-E2) and $2 \times 1 \mathrm{ml}$ of buffer containing $200 \mathrm{mM}$ imidazole (E3-E4).

\section{SDS-polyacrylamide gel electrophoresis}

SDS-PAGE was performed using mini-Protean ${ }^{\circledR}$ TGX $^{\mathrm{TM}}$ precast 4-15\% gels (Bio-Rad, UK) using standard protocols. ${ }^{42}$ Samples were mixed with an equal volume of gel loading buffer and heated to $80{ }^{\circ} \mathrm{C}$ for 5 minutes. $50 \mu \mathrm{l}$ of sample was loaded per lane except where otherwise stated. Gels were stained using Coomassie brilliant blue R-250 (National Diagnostics, USA).

\section{Peptide mass fingerprinting}

Protein bands were excised from SDS-PAGE gels using a scalpel blade and subjected to in-gel tryptic digestion using a commercially produced kit (Pierce, Thermo Scientific, UK). Peptide masses were determined by MALDI-TOF MS analysis. $2 \mu \mathrm{l}$ of sample matrix (10 $\mathrm{mg} \mathrm{ml}^{-1} \alpha$-cyano-4-hydroxycinnamic acid in $50 \%$ acetonitrile, $0.1 \%$ trifluoroacetic acid) was mixed with $2 \mu \mathrm{l}$ of sample and spotted onto a steel MALDI-target plate. Peptide masses were determined using a Bruker Ultraflex II MALDITOF/TOF mass spectrometer (Bruker Daltonics, Coventry, UK) with a $337 \mathrm{~nm}$ laser and operated in reflectron mode. Mass calibration was performed using PEG2000 and verified using bradykinin and substance $\mathrm{P}$ peptide standards. Internal mass accuracy was confirmed by the presence of the autolytic trypsin peaks at 845.2 and 2211.1 Da. Mass spectra were acquired over the range of 800-3500 Da. Mass lists were generated using Bruker Flex-analysis software with default parameters, and searched against either the NCBI or SwissProt databases using Mascot (Matrix Science, UK). The following search criteria were selected: Fixed modification of carbamidomethyl on cysteine, variable modification of oxidation of methionine, maximum of 1 missed cleavage, <50 ppm mass accuracy, "other bacteria" was selected for taxonomy. Only searches giving significant MOWSE scores were recorded.

\section{Structural models}

Comparative modelling was employed to provide insight into the likely structures of the ZnuA, FutA, CynA, and cyanobacterial porin (CBP) proteins. Suitable templates were identified using the remote homology recognition server Phyre ${ }^{2},{ }^{43}$ which also produces multiple and pairwise sequence alignments (see ESI $\dagger$ ), and in favourable cases sound protein models. All initial models were generated by Phyre ${ }^{2}$. The model for ZnuA was based on pdb 2OV3 (ZnuA from Synechocystis sp. PCC6803; mutant devoid of 
His-rich loop), ${ }^{44}$ that for CynA on pdb 3UN6 (Ligand Binding Component of ABC-type Import System from Staphylococcus aureus), ${ }^{45}$ and that for FutA was based on pdb 2PT1 (FutA from Synechocystis sp. PCC6803). ${ }^{46}$ The ZnuA and CynA models were further developed using the molecular modelling program MOE2011.10. Hydrogen atoms, zinc ions, and a cyanate ion in the case of CynA were introduced, and the metal sites were then energy-minimised, using an in-house customised version of the AMBER99 force-field, in which Zn-specific parameters were incorporated. After energy minimisation of the position of the immediate zinc ligands, the adjacent environment was optimised, and finally, the entire molecule was subjected to energy minimisation. All minimisations were terminated based on the steepness of the RMS gradient $(<0.5)$. Models were submitted to the wHATIF web interface (http://swift.cmbi.ru.nl/servers/html/index.html), ensuring that a physically reasonable model had been produced.

The 3D model for the CBP SYNW2224 was generated using the "Intensive mode" on the Phyre ${ }^{2}$ server, and is based on three overlapping templates: residues 46-98 are based on pdb 3PYW (SLH domain from Bacillus anthracis), ${ }^{47}$ residues $92-141$ on pdb 3SWF (a helix from a rod cyclic nucleotide-gated ion channel), ${ }^{48}$ and residues $134-501$ on pdb 4GF4 (Pseudomonas putida OprB, a porin for carbohydrate uptake). ${ }^{49}$ Structural images were generated in MOLMOL v.2k.1. ${ }^{50}$

\section{Results}

\section{Synechococcus sp. WH8102 grows well in zinc-depleted media}

To investigate if depletion of zinc may affect the growth of Synechococcus sp. WH8102, cultures were studied in an artificial seawater medium based on Aquil ${ }^{38,39}$ that was supplemented with either 0 (zinc-depleted medium) or $80 \mathrm{nM}$ (designated here as "replete" medium, although it should be noted that the resulting free zinc concentration is still very low) zinc. The presence of
$100 \mu \mathrm{M}$ EDTA leads to a theoretical free $\mathrm{Zn}^{2+}$ concentration of $16 \mathrm{pM}$ in the replete medium, with $98.98 \%$ of the added $\mathrm{Zn}^{2+}$ complexed. Free $\mathrm{Zn}^{2+}$ concentrations in open ocean surface waters vary from 1 to $71 \mathrm{pM}^{11-13,16}$ Hence, the free $\mathrm{Zn}^{2+}$ concentration in our replete medium is not dissimilar to those that Synechococcus sp. WH8102 might encounter in its natural habitat. The free ion concentrations are considered the most relevant factor governing uptake. ${ }^{51,52}$

The growth data in Fig. 1(a) show that the cultures grown with 0 or $80 \mathrm{nM}$ zinc exhibited no significant difference in growth rate or final cell yield. This suggests that Synechococcus sp. WH8102 either has no absolute requirement for zinc, or that it is able to scavenge trace amounts of zinc from the depleted growth medium, which are unavoidably introduced as a contaminant with other media components.

\section{Efficient zinc uptake at extremely low zinc concentrations}

In a subsequent experiment, following 19 days growth in either zinc depleted or replete medium, cells were harvested and the zinc and phosphorus content of crude cell lysates was measured by Inductively-Coupled-Plasma-Mass-Spectrometry (ICP-MS). The phosphorus levels were used as a proxy for biomass. The cells grown under zinc-depleted conditions had accumulated significant quantities of zinc, and no significant difference in the $\mathrm{Zn}: \mathrm{P}$ ratio was recorded between the two conditions tested (Fig. 1(b)).

The fact that significant amounts of zinc were captured by Synechococcus sp. WH8102 even at extremely low concentrations points to the existence of highly efficient uptake mechanisms. Significantly, analysis of 1-dimensional SDS-PAGE gels of the complete proteomes from cells grown under the two regimes revealed that the amount of an outer-membrane protein (SYNW2224) was markedly increased under zinc-depleted conditions suggesting a potential role in zinc acquisition for this protein (Fig. 1(c)). A second protein band was visibly diminished

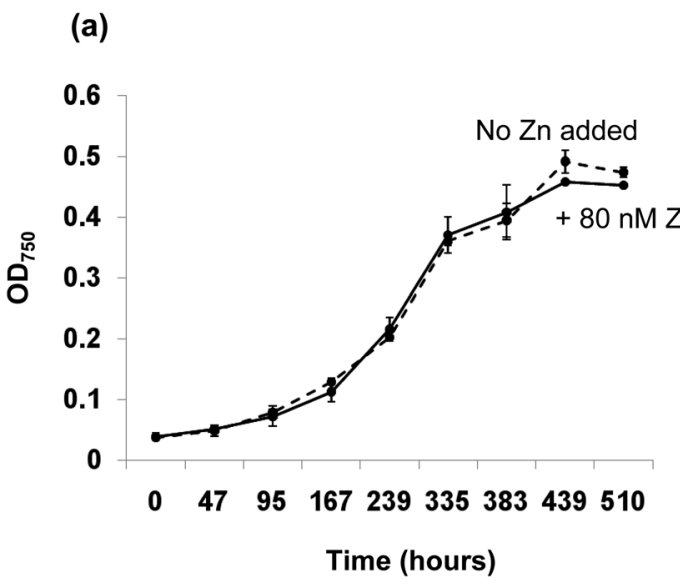

(b)

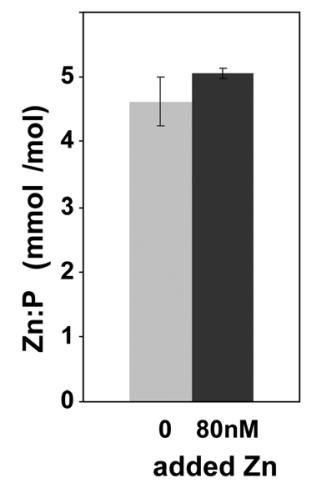

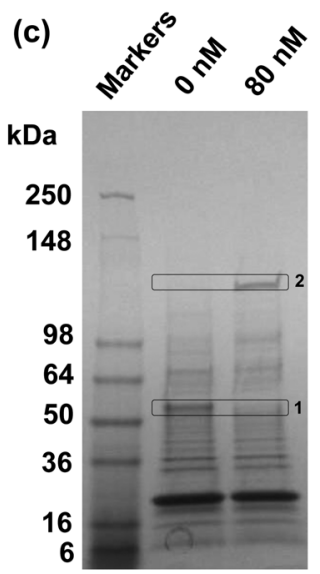

Fig. 1 Effect of zinc on the growth of Synechococcus sp. WH8102 and subcellular distribution of zinc. (a) Growth of Synechococcus sp. WH8102 in Aquil medium containing either $0 \mathrm{nM}$ (dashed line), or $80 \mathrm{nM}$ (solid line) added zinc. (b) Zn: phosphorus ratios in whole cells. (c) CBB-stained SDS-PAGE gel comparing the protein profiles of crude cell lysates prepared from Synechococcus sp. WH8102 cells grown in zinc depleted or replete media. $32 \mu \mathrm{g}$ of protein was loaded per lane. Proteins showing a marked difference in expression are boxed. Box 1 corresponds to a putative CBP (SYNW2224; identified with 14 matched peptides, 33\% sequence coverage and a MOWSE score of 78). Box 2 yielded the large subunit of RuBisCO as possible hit (6 matched peptides, $14 \%$ sequence coverage, MOWSE score 68). The large deviation between the observed and expected molecular weight could be due to persistence of the homo-dimer or a larger complex. ${ }^{115}$ 
under zinc-depletion conditions; this was tentatively identified as the large subunit of RuBisCO, although it is not clear why the observed molecular weight was considerably larger than expected, or why differences in zinc levels should affect the abundance of this protein.

\section{Fractionation of the zinc proteome by 2-dimensional liquid chromatography}

In an attempt to isolate intact $\mathrm{Zn}$-bound proteins from Synechococcus sp. WH8102, the soluble and insoluble proteomes, as well as carboxysomal fractions, were further fractionated using native 2-dimensional liquid chromatography (2D-LC). This approach was selected as it allows proteins to be separated rapidly and under mild conditions that promote the likelihood for keeping proteins folded and intact including moderately strongly bound metal cofactors. It should therefore in principle be suitable for the separation of $\mathrm{Zn}$-containing proteins that form relatively stable complexes. ${ }^{53}$ However, a drawback is the resolution of separation achievable by $2 \mathrm{D}-\mathrm{LC}$, which is considerably lower than that obtained using traditional denaturing 2D-gel electrophoresis methods. ${ }^{5}$

In the present study, proteins were initially separated using size exclusion chromatography (SEC), followed by anion exchange chromatography (AEX). The "insoluble" fraction was solubilised and separated in the presence of the mild detergent octyl glucoside, which has been used extensively for the isolation of native membrane proteins. ${ }^{54}$ In each case, $5 \mathrm{mg}$ total protein was applied to a BioSep S2000 HPLC gel filtration column and protein was eluted in $13 \times 1 \mathrm{ml}$ fractions. The elution fractions from four separate SEC runs were combined and applied to mini-spin anion exchange columns. These columns allowed the rapid and simultaneous separation and concentration of the gel-filtration fractions. Bound proteins were eluted from the anion exchange columns in $80 \mu \mathrm{l}$ fractions in a step-wise fashion using a NaCl gradient of 0-2 M. Each of the collected fractions was then analysed by ICP-MS for zinc content (Fig. 2). In the soluble fraction, zinc eluted from the gel filtration column as a single broad peak between $c a .14 \mathrm{kDa}$ and $70 \mathrm{kDa}$. In the insoluble fraction, two distinct peaks were observed, one at ca. $30-70 \mathrm{kDa}$ and a second at around $1 \mathrm{kDa}$, which contains peptides, other small molecules, and possibly also free metal ions. The proteins present in fractions with the highest zinc concentrations were analysed by SDS-PAGE (Fig. 2). For the soluble fraction, the anion exchange samples obtained from separation of the $9 \mathrm{ml}$ gel filtration fraction were analysed. Despite the concentration step, very few proteins were observed on the gel, but one protein migrating to $c a .18 \mathrm{kDa}$ on the gel could be observed even before staining by its light pink colour. This protein was identified by peptide mass fingerprinting and found to be a subunit of c-phycoerythrin, a component of the light harvesting phycobilisome complex. After the gel was stained with Coomassie, only one further protein (at $c a .10 \mathrm{kDa}$ ) could be visualised. This protein was identified as ribosome recycling factor, and neither of these two proteins is predicted to bind metal ions. However, like other biliproteins, c-phycoerythrin contains linear tetrapyrrole chromophores (phycobilins) with considerable metal-binding ability. It appears likely that cellular zinc has partially been redistributed to the chromophores on these proteins. In support of this hypothesis, several biliproteins were also captured on $\mathrm{Zn}^{2+}$-IMAC columns (see below). The redistribution of zinc in our samples might explain why no predicted zinc binding proteins including alkaline phosphatase or carbonic anhydrase were detected in the soluble fractions following 2D-LC. Similar results were obtained from the analysis of the insoluble cell fraction, with c-phycoerythrin again the most abundant protein present in the zinc enriched cell fractions (Fig. 2). The only other protein detected in the peak zinc fractions was PstS, a periplasmic phosphate binding protein. Whilst this protein is not predicted to bind zinc or any other metals in vivo, it was captured using a $\mathrm{Zn}^{2+}$-IMAC column (see below), suggesting that it has an affinity for zinc in vitro. Full details of the proteins identified are given in Table S2 (ESI $\dagger$ ). In the carboxysome fraction, zinc was only detected in lower molecular weight sub-fractions ( $20 \mathrm{kDa}$ and below), but the concentrations of proteins were too low for identification by peptide mass fingerprinting.

In conclusion, despite the rapid and mild separation conditions used for the chromatography and the relatively high stability of $\mathrm{Zn}^{2+}$ complexes according to the Irving-Williams series, ${ }^{53}$ no major zinc-binding proteins in any of the sub-cellular fractions could be identified by the 2D-LC approach. Major drawbacks were the low resolution of the separation steps and insufficient sensitivity in protein detection, both of which are exacerbated by the presence of highly abundant biliproteins. These pose a significant challenge for native metalloproteomics in this organism and likely other related cyanobacteria. In terms of classical massspectrometry-based proteomics, biliproteins cause dynamic range problems, since they can account for as much as $60 \%$ of total cellular protein; hence, they are inherently likely to impede the detection of low abundance proteins. In terms of native metalloproteomics, their demonstrated metal-binding ability (also see below) causes additional problems, as this may lead to metal redistribution in cell lysates - a problem unlikely to be solvable by depletion strategies.

\section{Enrichment of zinc-binding proteins by immobilized metal ion affinity chromatography}

Metal-trafficking proteins often bind their cargo in a kinetically labile fashion and close to the protein surface, to enable facile transfer to and from other molecules. This is an ideal prerequisite to capture such proteins by immobilized metal ion affinity chromatography (IMAC). Similar approaches have been used in previous studies to isolate proteins that have an affinity for the immobilised metal ion in vitro, e.g. proteins with copper affinity from human liver cells, ${ }^{55}$ Arabidopsis thaliana,${ }^{56}$ and microalgae, ${ }^{57}$ and metal-binding proteins from plant mitochondria. ${ }^{58}$

Eluates from a $\mathrm{Zn}^{2+}$-IMAC column were analysed by 1D SDSPAGE (Fig. 3), and proteins were identified by peptide mass fingerprinting. A total of 30 different proteins with zinc-binding ability were identified (Table 1), including several enzymes, biliproteins, carboxysomal shell proteins, periplasmic binding proteins, and two outer membrane proteins. Based on biochemical 

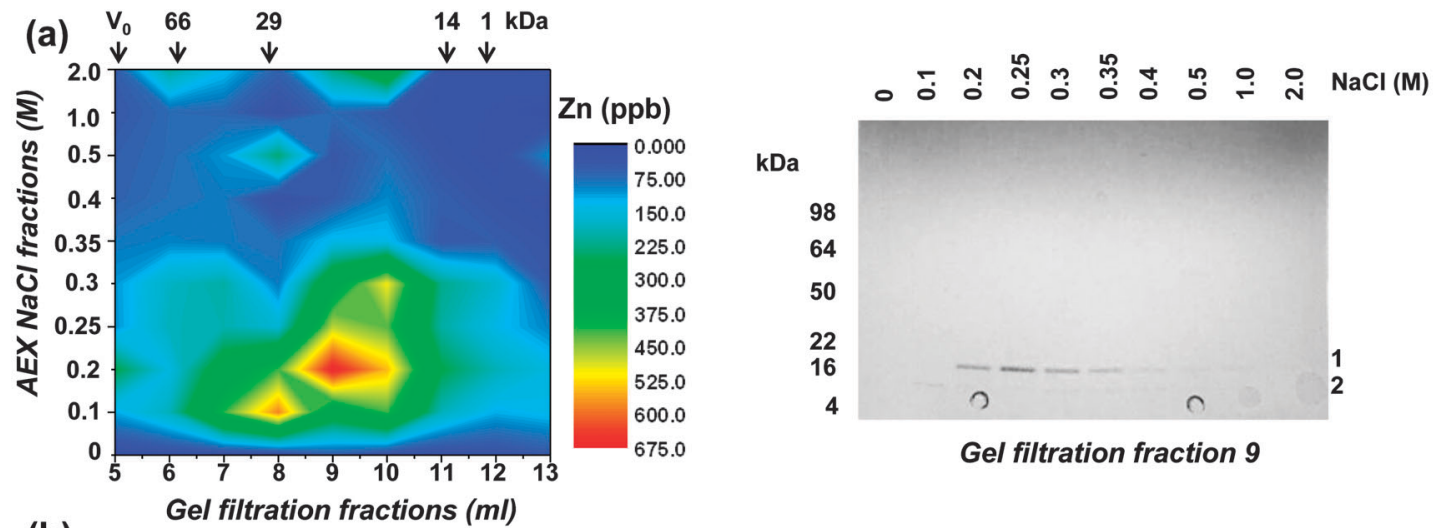

(b)
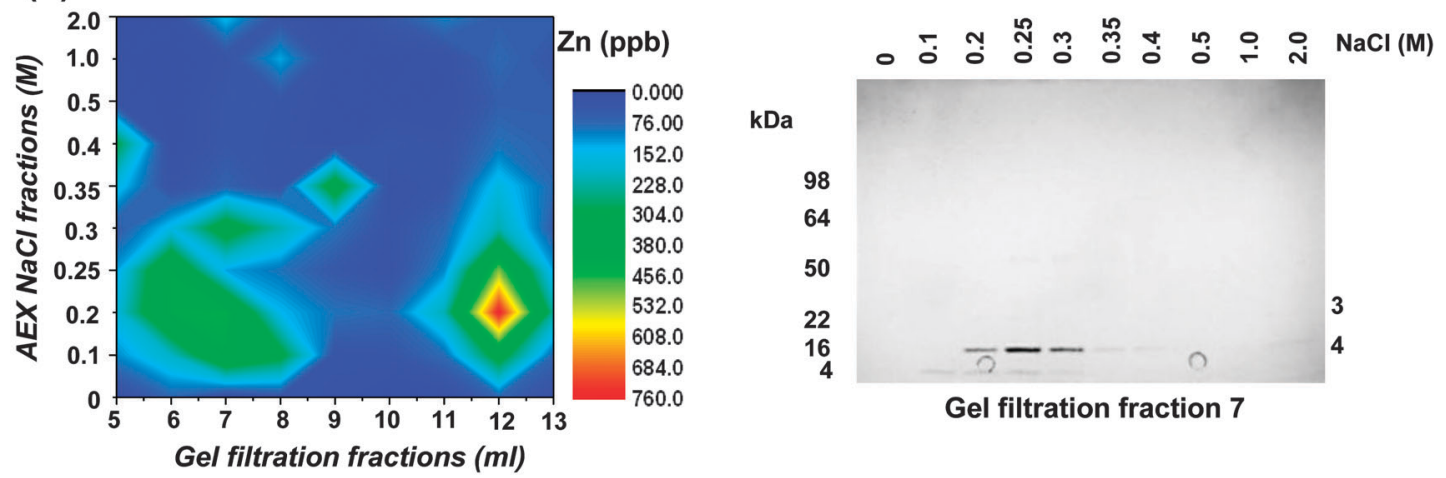

(c)

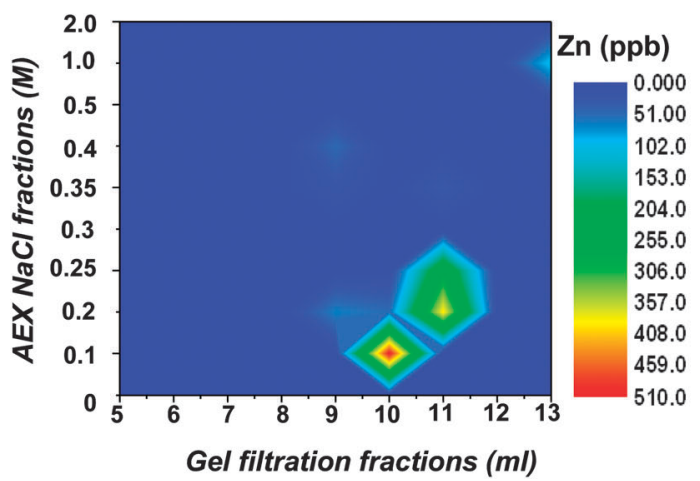

Fig. 2 Two-dimensional liquid chromatography separation of the zinc proteome of Synechococcus sp. WH8102. Proteins present in the (a) soluble, (b) insoluble, and (c) carboxysome cell fractions were separated by gel filtration and anion exchange chromatography. The zinc contents of collected fractions were measured by ICP-MS and the data plotted. The elution of molecular weight markers (BSA - $66 \mathrm{kDa}$, carbonic anhydrase - $29 \mathrm{kDa}$, lysozyme $-14 \mathrm{kDa}$, and substance $\mathrm{P}-1 \mathrm{kDa}$ ) from the gel filtration column is indicated with arrows. Right hand panels are CBB-stained SDS-PAGE gels showing proteins present in peak zinc containing fractions following 2D-LC separation. The motilities of molecular weight markers are indicated on the left of the gels and the proteins identified (Table S2, ESI $\dagger$ ) are numbered on the right. Bands 1 and 4 are MpeA, a component of c-phycoerythrin, band 2 is ribosome recycling factor, and band 3 (very faint) is PstS. None of these proteins are predicted to bind metal ions.

data from homologous proteins, some of these proteins are predicted to bind metal ions; others, including biliproteins and carboxysomal shell proteins, are not. Identified proteins are described and discussed below.

Enzymes and regulatory proteins. Amongst the proteins captured, there were several enzymes predicted to require zinc for function, including fructose bisphosphate aldolase (SYNW0791), transketolase (TktA; SYNW0141), dihydrolipoyl dehydrogenase (LdpA; SYNW1630), RNA polymerase, and a putative alkaline phosphatase. A related fructose bisphosphate aldolase from the protozoan Giardia lamblia (pdb 3GAK) coordinates a zinc ion via two His and one Glu residue, with a further Asp residue that can contribute to an alternative binding site nearby. ${ }^{59}$ All of these zinc-binding residues are conserved in the protein from Synechococcus sp. WH8102, which otherwise is $43 \%$ identical to the enzyme from $G$. lamblia. The zinc site in the G. lamblia protein is mobile and at least the two His residues are fairly surface-exposed, with the potential for exchange between any eventual protein-bound metal and immobilised zinc on the IMAC column. Whilst we also note that fructose bisphosphate 


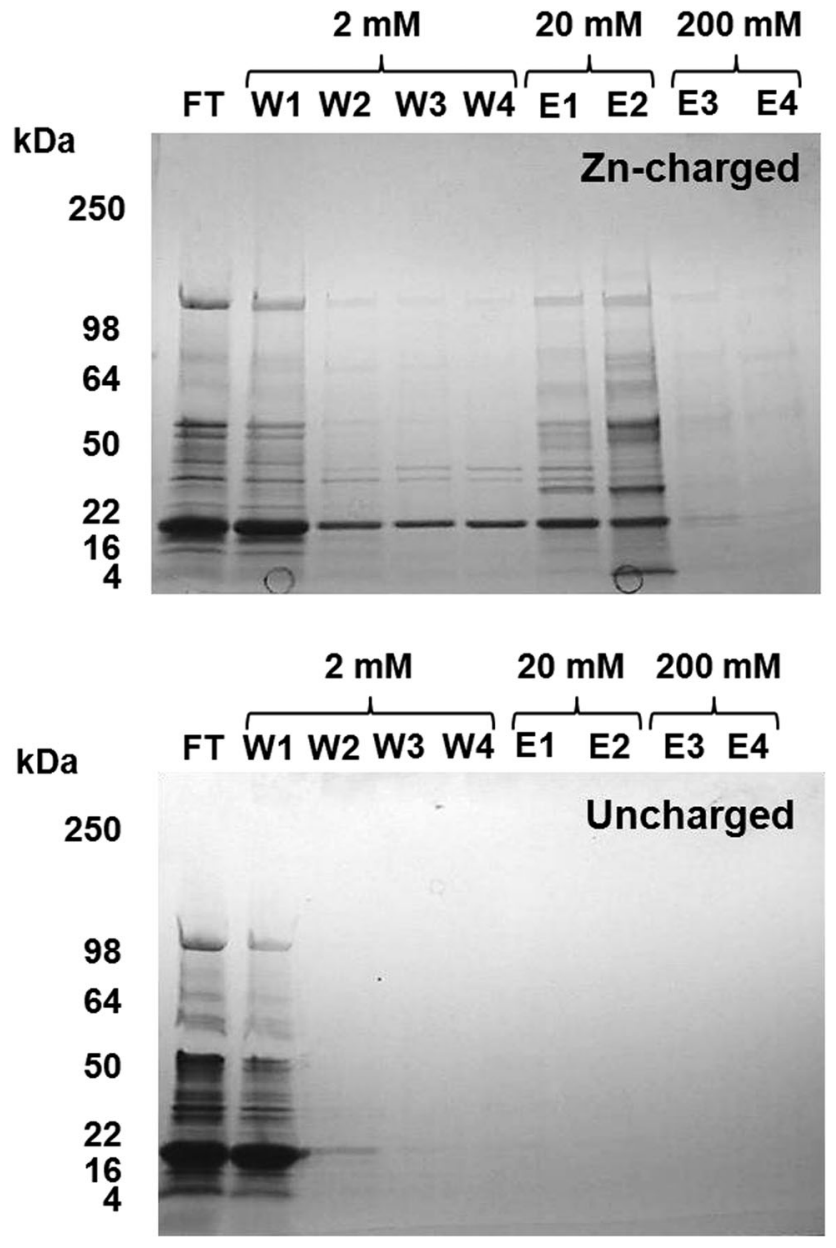

Fig. 3 Isolation of zinc binding proteins by $\mathrm{Zn}^{2+}-\mathrm{IMAC}$. CBB-stained gel of $\mathrm{Zn}$-IMAC column fractions. $20 \mathrm{mg}$ of crude cell lysate was applied to a $1 \mathrm{ml} \mathrm{Zn-IMAC}$ column and the flow-through (FT) collected. Unbound protein was washed through the column using buffer containing $2 \mathrm{mM}$ imidazole (W1-W4). Strongly bound protein was eluted using buffer containing 20-200 mM imidazole (E1-E4). Proteins present in the elution fractions were identified by peptide mass fingerprinting (Table 1 ).

aldolase from Synechocystis showed the highest activity with $\mathrm{Co}^{2+}, 60$ it must be stressed that neither interaction with a particular IMAC column nor enzymatic activity assays give a conclusive answer as to the in vivo bound metal ion(s).

The enzymes transketolase (TktA) and dihydrolipoyl dehydrogenase (LpdA) from $E$. coli were previously found to bind ${ }^{65} \mathrm{Zn}$ after separation of the proteome by denaturing $2 \mathrm{D}$ gel electrophoresis. ${ }^{61}$ More recently, in vivo zinc binding was demonstrated for both enzymes by in vivo labelling with ${ }^{65} \mathrm{Zn}$ and subsequent separation by native $2 \mathrm{D}$ gel electrophoresis. ${ }^{62}$ TktA from $E$. coli (pdb 2R8O) ${ }^{63}$ contains at least six His residues in its substrate-binding pocket, which are fully conserved in the homologue from Synechococcus sp. WH8102. These His residues are involved in binding the diphosphate moiety, the sugar hydroxyls, and the phosphate of the D-fructose- 6 phosphate thiamine diphosphate adduct. Thus, although they might contribute to the observed affinity for zinc, an in vivo zinc-binding role is unlikely. LpdA (pdb 4JDR for the enzyme from E. coli) ${ }^{64}$ abounds with surface-exposed metal-binding residues. The CHED server for automatic metal site recognition, which takes into account the main metal-binding residues (Cys, His, Glu, Asp; http://ligin1.weizmann.ac.il/ lpgerzon/mbs4/mbs.cgi) ${ }^{65}$ detected no less than seven possible metal sites, even though the published structure is devoid of any metal ions. With the exception of one site involving two Asp and one Glu residue, none of these sites are conserved in the enzyme from Synechococcus sp. WH8102. Whether the latter site is of significance regarding enzymatic activity is unknown.

In addition, several further enzymes were also captured on the IMAC column. Using structural models, CHED analysis, and manual inspection, possible reasons for this are explored below. Glutaredoxin (modelled on pdb 3QMX, from Synechocystis ${ }^{66}$ ) contains three Cys residues, and one of them is flanked by a His and an Asp residue, both surface-accessible, hence in principle suitable for IMAC capture. Rubrerythrin from Desulfovibrio vulgaris (pdb $1 \mathrm{DVB}^{67}$ ) contains binding sites for three iron ions, one $\mathrm{Cys}_{4}$ site, and a binuclear site, which are conserved in RbrA from Synechococcus sp. WH8102. As a relatively weakly-binding metal ion, $\mathrm{Fe}^{2+}$ is prone to be lost during protein separation. Thus, in principle, sites in Fe-proteins may become available for binding to immobilised metal. The most surface-accessible residues are two Cys residues, whereas the His and Glu residues in the binuclear site are buried in the folded protein, and are not clustered in the primary sequence, so relatively unlikely to be responsible for IMAC binding.

SYNW2391 is annotated as a putative alkaline phosphatase, is structurally related to 7-bladed $\beta$-propeller oxidoreductases, and contains an abundance of potential metal sites (CHED detected seven sites in total). Similarly, at least five metalbinding sites can be identified in glutamine synthetase (GlnA). The protein is 55\% identical to GlnA from Salmonella typhimurium (pdb $1 \mathrm{FPY}^{68}$ ). One large, surface-exposed site involving several Glu and His residues is the ATP-binding site, which also requires two $\mathrm{M}^{2+}$ ions for binding and ATP hydrolysis. Essentially similar considerations hold for the beta' subunit of RNA polymerase RpoC2 which also harbours a Mg-requiring ATPbinding site. In addition, a structural $\mathrm{ZnCys}_{4}$ site is present, but this is deeply buried (RpoC2 was modelled on pdb 4G7O, RNA polymerase from Thermus thermophilus ${ }^{69}$ ). Similarly, the large subunit of RuBisCO harbours three potential metal sites, one of them coinciding with the binding site for ribulose-1,5bisphosphate, which also requires a $\mathrm{Mg}^{2+}$ ion. ${ }^{70}$ It is hence conceivable that similar ternary complexes can also be formed with NTA-immobilised $\mathrm{Zn}^{2+}$ (or indeed other immobilised metal ions). $O$-Acetyl-homoserine sulfhydrylase also displayed three potential metal sites, one of them containing a Cys residue, but not related to enzymatic activity. Phosphoglucomutase, glucose-6-phosphate isomerase, and the oligosaccharide phosphorylase GlgP are all part of sugar metabolism, and are enzymes that work in sequence. GlgP is required for the breakdown of oligosaccharides, resulting in glucose-1-phosphate. This is converted to glucose-6-phosphate by phosphoglucomutase, and this is converted to fructose-6-phosphate by the isomerase. Several oligosaccharide phosphorylases are reported to be 
Table 1 List of proteins binding to $\mathrm{Zn}^{2+}$-charged IMAC columns

\begin{tabular}{|c|c|c|c|c|c|}
\hline Mass (kDa) & Gene (cluster) ${ }^{a}$ & Protein name & $\begin{array}{l}\text { No. peptides } \\
\text { matched }\end{array}$ & $\begin{array}{l}\text { \% Sequence } \\
\text { coverage }\end{array}$ & $\begin{array}{l}\text { MOWSE } \\
\text { score }\end{array}$ \\
\hline \multicolumn{6}{|l|}{ Enzymes } \\
\hline 9.4 & $\operatorname{synw} 2310^{445}$ & Glutaredoxin & 7 & 67 & 70 \\
\hline 25.9 & $r b r A^{1682}$ & Rubrerythrin & 15 & 55 & 153 \\
\hline 34.3 & $h e m C^{643}$ & Porphobilinogen deaminase & 12 & 43 & 80 \\
\hline 38.5 & $c b b A^{976}$ & Fructose bisphosphate aldolase & 7 & 25 & 71 \\
\hline 47.1 & $\operatorname{cys} D^{1284}$ & $O$-Acetyl homoserine sulfhydrylase & 12 & 42 & 67 \\
\hline 51.3 & $\operatorname{lpd} A^{102}$ & Dihydrolipoyl dehydrogenase & 9 & 30 & 78 \\
\hline 52.0 & $\operatorname{atpB}^{1107}$ & ATP synthase subunit beta & 7 & 21 & 90 \\
\hline 52.8 & $c c b L^{681}$ & Ribulose-1,5-bisphosphate carboxylase/oxygenase large subunit & 11 & 49 & 87 \\
\hline 52.5 & $g \ln A^{103}$ & Glutamine synthetase, glutamate ammonia ligase & 9 & 23 & 100 \\
\hline 58.9 & $\operatorname{pgm}^{1145}$ & Phosphoglucomutase & 13 & 39 & 76 \\
\hline 63 & synw $2391^{5416}$ & Alkaline phosphatase & 9 & 24 & 77 \\
\hline 60.3 & $p^{8 i^{827}}$ & Glucose-6-phosphate isomerase & 12 & 29 & 95 \\
\hline 72.2 & $t k t A^{291}$ & Transketolase & 25 & 42 & 165 \\
\hline 95 & $g \lg P^{118}$ & Phosphorylase & 11 & 18 & 76 \\
\hline 148.4 & rpoC2 $2^{1059}$ & DNA directed RNA polymerase subunit beta' & 32 & 31 & 190 \\
\hline \multicolumn{6}{|c|}{ Components of phycobilisomes } \\
\hline 18 & $m p e B^{8005}$ & C-phycoerythrin class 2 subunit beta & 9 & 54 & 75 \\
\hline 17.7 & $m p e A^{7994}$ & C-phycoerythrin class 2 subunit alpha & 12 & 71 & 112 \\
\hline 32 & mpeC $^{8012}$ & C-phycoerythrin class II gamma chain, linker polypeptide & 21 & 74 & 218 \\
\hline 59.4 & $m p e D^{8022}$ & Phycobilisome linker polypeptide & 24 & 43 & 159 \\
\hline \multicolumn{6}{|c|}{ Components of carboxysomes } \\
\hline 10.6 & $c c m K 1^{8056}$ & CcmK1 & 16 & 99 & 169 \\
\hline 18.3 & $c c m K^{237}$ & $\mathrm{CcmK2}$ & 9 & 62 & 124 \\
\hline \multicolumn{6}{|c|}{ Transcription and translation factors } \\
\hline 27.7 & $r p a B^{8013}$ & Two component response regulator & 11 & 48 & 75 \\
\hline 43.6 & tuf $f^{494}$ & Elongation factor Tu & 22 & 64 & 140 \\
\hline 75.1 & fusA $^{495}$ & Elongation factor $\mathrm{G}$ & 28 & 46 & 160 \\
\hline \multicolumn{6}{|c|}{ Periplasmic binding proteins } \\
\hline 33.2 & $z n u A^{2462}($ synw2481) & Zn ABC transporter, substrate binding protein & 6 & 25 & 79 \\
\hline 33.8 & $p_{s t S^{23}}($ synw1018) & $\mathrm{ABC}$ transporter, substrate binding protein, phosphate & 11 & 33 & 142 \\
\hline 37.7 & futA ${ }^{68}$ & Fe ABC transporter, substrate binding protein & 17 & 60 & 154 \\
\hline 60.5 & synw $2487^{2165}$ & Cyanate $\mathrm{ABC}$ transporter, substrate binding protein & 8 & 35 & 85 \\
\hline \multicolumn{6}{|l|}{ Porins } \\
\hline 53.8 & synw $2224^{8}$ & Porin & 18 & 43 & 135 \\
\hline 51.2 & synw $2227^{8}$ & Porin & 7 & 24 & 79 \\
\hline
\end{tabular}

activated, stimulated, or inhibited by various metal ions (http:// www.brenda-enzymes.info/php/ result_flat.php4?ecno=2.4.1.1), suggesting the presence of metal binding sites, and indeed, six potential sites were detected by CHED. Most phosphoglucomutases require $\mathrm{Mg}^{2+}$ for activity, but show limited activity with various other metal ions. The Synechococcus sp. WH8102 phosphoglucomutase shares 51\% identity with that from the ciliate Paramecium tetraaurelia (pdb $1 \mathrm{KFI}^{71}$ ), which has been crystallised with $\mathrm{Zn}^{2+}$ bound. One of the sites identified by CHED coincides with this Zn-binding site, but it is deeply buried and hence unlikely to explain the IMAC interaction. Although archaeal glucose-6-phosphate isomerases have been isolated with zinc and iron bound, ${ }^{72,73}$ they are structurally not related to the corresponding bacterial and eukaryotic enzymes, for which no metal requirements or inhibition are reported. CHED identified nevertheless four potential binding sites, one of them comprising five amino acid side-chains.
The two-component response regulator $\mathrm{RpaB}$ is a two-domain protein, and two potential metal-binding sites in its N-terminal domain were detected by CHED. It shares $42 \%$ identity with the RegX3 regulator from Mycobacterium tuberculosis (pdb $2 \mathrm{OQR}^{74}$ ), and the crystal structure of the latter has been stabilised by $\mathrm{La}^{3+}$ ions, although metals are not thought to play a role in the activity of this protein. The metal-binding residues in RpaB and RegX3 are not identical, but the location of the exposed N-terminal sites is roughly similar. Elongation factor Tu displays an abundance of clustered, surface-exposed His and Glu residues forming at least three sites, with no clear functional significance, and not related to the GTP-binding site. ${ }^{75}$ Two potential metal binding sites can be predicted for elongation factor $\mathrm{G}$, again without relationship to known protein function. ${ }^{76} \mathrm{CHED}$ analysis of structural models of subunit beta of ATP synthase and porphobilinogen deaminase did not reveal any pertinent metal binding sites.

Carboxysomal proteins. Two carboxysomal shell proteins, annotated as CcmK/CsoS1 (SYNW1719) and CcmK2 (SYNW1712) 
were captured on the Zn-IMAC column. $\neq$ In a previous study, we found that CcmK1 also had a strong affinity for $\mathrm{Co}^{2+}$-IMAC columns. ${ }^{37}$ Considering that the carboxysomes also house carbonic anhydrase, the unexpected affinity for zinc and cobalt displayed by the CsoS1 proteins was intriguing. Fig. S1 (ESI $\dagger$ ) shows a homology model for CcmK1 (103 aa), which adopts a typical bacterial microcompartment domain fold. The larger Ccmk2 (183 aa, modeled using pdb 3NWG, a PduT homolog from a novel bacterial microcompartment from Desulfitobacterium hafniense) ${ }^{77}$ contains two such domains (see Fig. S2, ESI $\dagger$ ). Both proteins display similar surface-exposed patches of potential metal ligands (Glu, His), although the CHED program did not report any metal sites in either protein, even under the least stringent search conditions. Since these proteins form multimeric complexes as part of the carboxysome shell, a hexameric assembly of a closely related CsoS1 protein was also inspected (pdb 2EWH; CsoS1A from Halothiobacillus neapolitanus), ${ }^{78}$ but no additional inter-protein metal sites were detected. It is conceivable that the loop containing E86, H88 and E90 (CcmK1 numbering; the same motif is also present in the C-terminal portion of CcmK2) is flexible enough to provide a metal-binding motif with sufficient affinity for binding to an IMAC column, at least in the monomeric protein. We note that the pore structures formed by the structurally related ethanolamine-utilising microcompartment shell protein, EutL from $E$. coli, were affected by the presence of $\mathrm{Zn}^{2+}, 79$ but in neither case is it clear yet whether an interaction between microcompartment shell proteins and $\mathrm{Zn}^{2+}$ is of physiological relevance, or only occurs in vitro.

Periplasmic binding proteins. The ZnuA component (SYNW2481) of a putative ZnuABC zinc uptake transporter was identified in the Zn-IMAC eluate, confirming its expression, and supporting the hypothesis that this system could operate in zinc uptake in Synechococcus sp. WH8102. True ZnuA proteins can often be distinguished ${ }^{28}$ from the closely related $\mathrm{Mn}^{2+}$ binding proteins $(\mathrm{MntC})^{80}$ by the presence of a His-rich loop (in ZnuA), but the putative ZnuA orthologues from Synechococcus sp. WH8102§ are unusual in that they do not contain this His-rich loop. Both MntCs and ZnuAs contain three strictly conserved His residues in their folded part that are involved in forming the major metal-binding site. A homology model for SYNW2481 (Fig. 4(a)) shows the protein fold including this binding site.

However, several other periplasmic binding proteins were also captured on the Zn-IMAC column, including putative iron (FutA/IdiA; SYNW1797), cyanate (CynA; SYNW2487), and phosphate (PstS; SYNW1018) transporters. The interaction of the ironbinding protein FutA with the immobilised $\mathrm{Zn}^{2+}$ is unsurprising, because a certain degree of affinity for a non-cognate metal ion can be expected based on simple coordination chemistry principles. In contrast, the capture of the predicted cyanate (CynA) and phosphate (PstS) binding proteins was surprising.

\$ Since WH8102 contains $\alpha$ carboxysomes, the term CsoS1 should be used (Badger and Price, 2003) - ccm (for carbon-concentrating mechanism) proteins are components of $\beta$ carboxysomes, but this nomenclature is widely ignored in genome annotations; therefore, we have retained the names as they appear in relevant databases.

$\S$ SYNW0971 is also predicted as ZnuA.
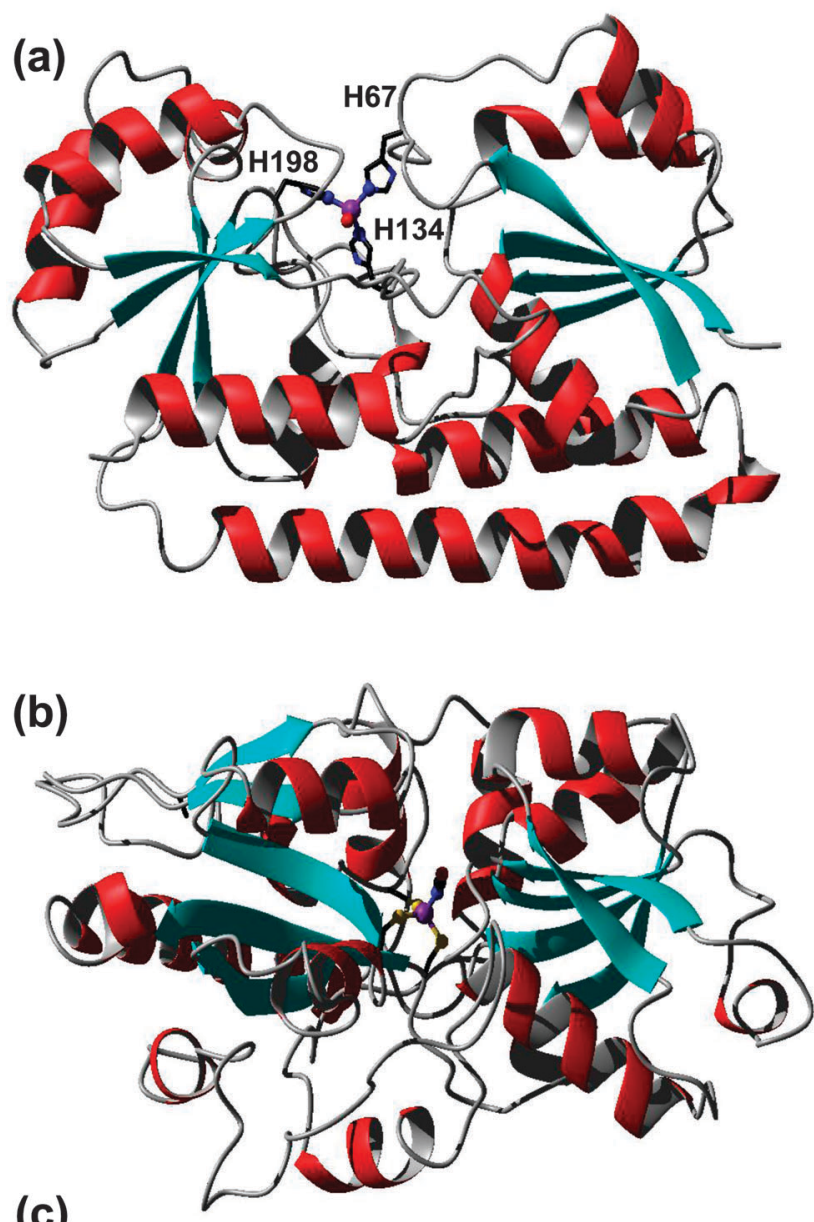

(c)

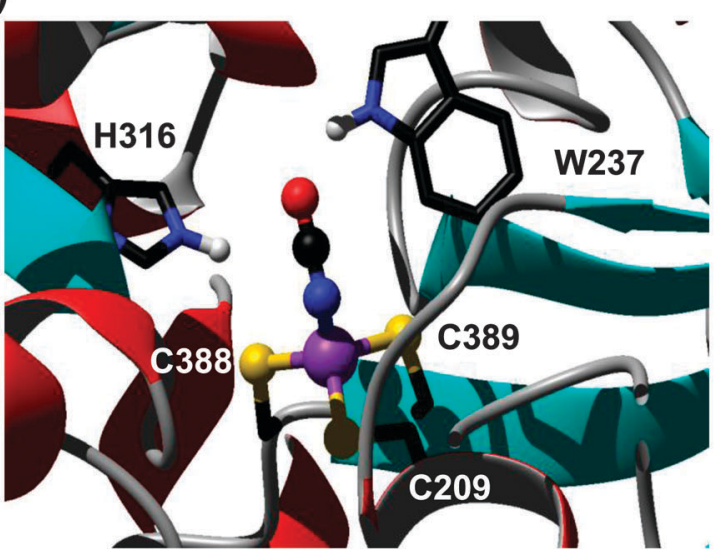

Fig. 4 Modelled metal-binding sites in periplasmic binding proteins captured on a Zn-IMAC column. (a) Putative ZnuA (SYNW2481) from Synechococcus sp. WH8102. The zinc ion is coordinated to three His residues $(\mathrm{H} 67, \mathrm{H} 139, \mathrm{H} 198)$ and a fourth non-proteinaceous ligand, modelled as water. (b) Putative cyanate transporter CynA (SYNW2487). The model (residues 197-520) is based on pdb $3 \cup N 6,{ }^{45}$ an uncharacterised protein from Staphylococcus aureus. Zinc is coordinated to three Cys residues and a cyanate ion. The fold of the modelled CynA protein is very similar to that of periplasmic nitrate and hydrogen carbonate binding proteins, but none of the metal-binding residues are conserved in either nitrate or hydrogen carbonate transporters from Synechocystis sp. PCC6803. (c) Detailed view of the metal- and cyanate-binding site, with His316 and Trp237 as potential $\mathrm{H}$-bond donors. 
Therefore, homology models for both latter proteins were generated to inspect potential metal-binding sites. The model for the phosphate binding protein PstS did not reveal any clear metal sites (not shown). In contrast, one of the templates identified for the cyanate transporter CynA contained zinc ions in the binding cleft, one of them coordinated to two Cys and one His residue plus one water molecule. The template (pdb $3 \mathrm{UN} 6)^{45}$ refers to an uncharacterised protein from Staphylococcus aureus. Like CynA, this protein is most closely related to the COG0715 cluster which contains periplasmic components of ABC-type nitrate-sulfonate-bicarbonate transport systems. The two Cys residues are conserved in CynA, and the His residue is replaced by another Cys residue (Fig. 4(b) and (c)). It is likely that at least some of these residues are responsible for the observed interaction with the immobilised $\mathrm{Zn}^{2+}$, and considering the nature of the ligands, in vivo $\mathrm{Zn}^{2+}$ and/or $\mathrm{Cd}^{2+}$ binding is most likely. It is plausible that the metal ion facilitates the binding of the cyanate anion to be transported. Considering that $\mathrm{Zn}^{2+}$ (or any other metal ion) is needed only in catalytic quantities inside cells, whilst cyanate provides the macronutrient nitrogen, co-transport of the metal appears less likely. It is noteworthy that the orthologous bicarbonate transporter CmpA from Synechocystis sp. PCC6803 utilises a $\mathrm{Ca}^{2+}$ ion to enhance bicarbonate binding. ${ }^{81}$

Outer membrane proteins. Perhaps most intriguingly, a predicted outer membrane protein, (SYNW2224) that was found to be more abundant under low-zinc conditions (Fig. 1(c)), was also one of the proteins captured on the Zn-IMAC column, along with a second putative outer membrane protein (SYNW2227). Both proteins belong to the family of cyanobacterial porins (CBP; TC 1.B.23). Two homologues from the freshwater strain Synechococcus sp. PCC7942 (SYNPCC7942_1464 and SYNPCC7942_1463; termed SomA and SomB, for Synechococcus outer-membrane protein A and B) have been extensively studied. ${ }^{82,83}$ In contrast to carbohydrate-translocating porins from heterotrophic bacteria, the single-channel conductance of SomA suggested that small solutes, most likely ions, are transported, ${ }^{84}$ but the actual substrates have not been identified.

To enable the inspection of SYNW2224 for potential metalbinding sites, we generated a coarse model with the aid of the Phyre $^{2}$ server (Fig. 5). The model shows a 16-stranded $\beta$-barrel, an $\mathrm{N}$-terminal S-layer homology domain, connected by a long amphipathic helix. The S-layer domain, the helix, as well as several loops (both extra- and intracellular) abound in carboxylate groups, which might provide metal ion interaction sites, although it should be noted that the number of positively and negatively charged sidechains in SYNW2224 is overall similar. Many other marine CBPS (Table S3, ESI $\dagger$ ) have a pronounced over-abundance of negatively charged side-chains. The model also suggests that the 'pore' is probably constricted by several loops, consistent with the hypothesis that these porins transport simple inorganic ions.

\section{Discussion}

The ability of Synechococcus sp. WH8102 cultures to grow at extremely low zinc concentrations and maintain cellular

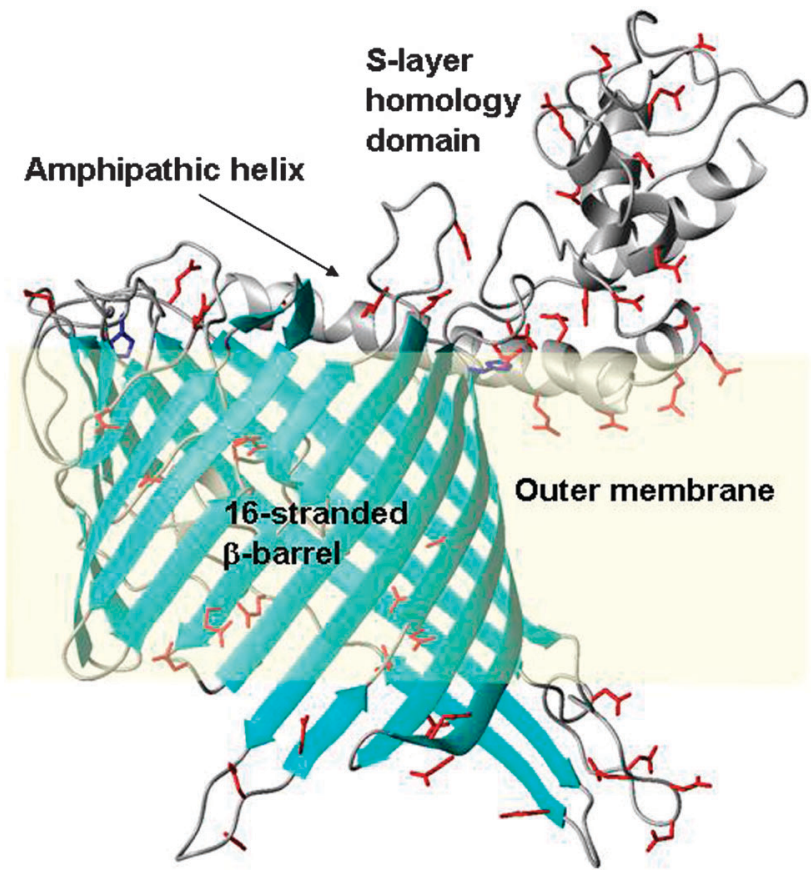

Fig. 5 Predicted structural features of a putative outer membrane porin from Synechococcus sp. WH8102. The topology and distribution of potential metal-binding residues (predominantly Asp and Glu, in red) of the SYNW2224 protein is indicated. The approximate location of the membrane is indicated in light yellow. Note that structural details, such as the orientation of the amphipathic helix, are unlikely to be reflected correctly in this model, but that it is shown to illustrate the presence and positioning of the major features as labelled.

zinc homeostasis, as judged by total zinc quotas, suggests that Synechococcus sp. WH8102 has extremely efficient zinc uptake mechanisms capable of scavenging zinc even from depleted media. Only slight, if any, growth limitation at extremely low free zinc concentrations has previously been observed for Synechococcus bacillaris $^{23}$ and Prochlorococcus MED4, ${ }^{24}$ especially when cobalt concentrations were also low, pointing to potential co-limitation by these two metal ions, and to possible substitution of zinc by cobalt but not vice versa. ${ }^{24,85}$

The mechanisms for metal ion uptake in marine cyanobacteria are only partially understood. Genes for DNA-binding metal sensor proteins of the Fur family are present in all available genomes, ${ }^{29}$ as are those for $\mathrm{ABC}$ transporters for $\mathrm{Fe}, \mathrm{Mn}$, and $\mathrm{Zn} .^{28,30}$ Little is known regarding transport across the outer membrane, but considering that metal ions such as $\mathrm{Fe}^{3+}$ and $\mathrm{Zn}^{2+}$ must be bio-accumulated by a factor of at least $10^{5}$, it follows that uptake mechanisms, including transport across the outer membrane, must be highly efficient.

One principal possibility is that zinc is transported into the cell as a complex with a chelating ligand. This option typically involves TonB-dependent receptors, ${ }^{86}$ which actively (i.e. under consumption of ATP) transport metal complexes with organic ligands across the outer membrane. TonB-dependent receptors are widely involved in bacterial iron uptake, but have also been implicated in bacterial zinc uptake, including four examples in Pseudomonas protegens $\mathrm{PF}-5$ in zinc-depleted soil, ${ }^{87}$ two examples 
in the opportunistic pathogen Acinetobacter baumannii, ${ }^{88}$ and a protein named "ZnuD" produced by pathogenic Neisseria meningitidis under zinc limitation. ${ }^{89}$ In the freshwater cyanobacterium Anabaena sp. PCC 7120, zinc starvation caused the upregulation of a Zur-regulated TonB-like receptor. ${ }^{27}$ However, even though tonB-like genes have been discovered in Prochlorococcus, ${ }^{90}$ most marine Synechococcus strains lack the respective proteins. $^{30,31,91,92}$ This absence of TonB-dependent receptors means that no specific outer membrane transporters for any $\mathbf{M}^{2+}$ or $\mathbf{M}^{3+}$ metal ion, including $\mathrm{Fe}^{3+}$, are known for marine Synechococcus.

Our discovery that the putative porins SYNW2224 and SYNW2227 have metal-binding ability offers a new hypothesis regarding the uptake of scarce trace metal ions by Synechococcus from oligotrophic waters, namely that at least some cyanobacterial porins of the CBP family play a central role in this process. The SYNW2224 model generated (Fig. 5) does not reveal any clearly defined binding sites, but many surfaceaccessible negatively charged carboxylate residues. On the basis of the nature and distribution of these potential metal-binding residues, the specificity of CBPs is expected to be limited, since all $\mathrm{M}^{2+}$ or $\mathrm{M}^{3+}$ species have significant affinities for clusters of carboxylate groups. Indeed, SYNW2224 was also captured on a $\mathrm{Co}^{2+}$-IMAC column in our previous study. ${ }^{37}$ The S-layer homology domain portion, and the amphipathic helix of SYNW2224, are also rich in negative charges, and hence may contribute to attracting and scavenging metal ions. In fact, a role for S-layers in biosorption of metals has been shown for bacilli, ${ }^{93}$ and the metal uptake process in cyanobacteria has recently been shown to involve a surface-adsorption step. ${ }^{94}$

Evidence that porins may function in metal uptake is available at the transcriptional level for other bacteria; for example, the expression of the porin OmpT in Vibrio cholerae is dependent on the level of iron in the environment, and is positively regulated by the ferric uptake regulator, Fur. ${ }^{95}$ The outermembrane protein MnoP in Bradyrhizobium japonicum is expressed under conditions of manganese limitation, and is required for high-affinity manganese uptake. ${ }^{96}$ In Mycobacterium tuberculosis the porin MspA has been shown to be required for copper uptake across the outer cell membrane, with mspA deletion mutants showing severe growth defects when grown in a trace copper medium. ${ }^{97}$ The expression of several porins was also zinc-dependent in Pseudomonas protegens, ${ }^{87}$ and that of the OprD porin in Pseudomonas aeruginosa is down-regulated by excess zinc. ${ }^{98}$

Significantly, in freshwater Synechococcus sp. PCC7942, the gene for the CBP $\operatorname{somB}$, but not its neighbouring CBP gene $\operatorname{som} A$, has been found to be up-regulated under iron starvation. ${ }^{99}$ somA and $\operatorname{somB}$ do not form an operon, but each have their own transcription start sites. ${ }^{100}$ Importantly, the upstream region of the $\operatorname{somB}$ gene in the PCC7942 strain is predicted by RegPrecise ${ }^{101}$ to contain a recognition site for the zinc-uptake regulator protein Zur. Hence, its expression is likely also zinc-regulated. RegPrecise also predicts zur boxes for CBP homologues in Thermosynechococcus elongatus (tlr1246), Microcystis aeruginosa (MAE_10010), and Synechocystis sp. PCC6803 (sll1550), and therefore proposed the name OmpZ (for zinc-regulated outer-membrane protein) for these homologues. Most cyanobacterial strains, including marine strains, have multiple CBP genes (Table S3, ESI $\dagger$ ), with Synechococcus sp. WH8102 having at least four (synw2128, synw2223, synw2224, symw2227). The most divergent cyanobacterial strain, Gloeobacter violaceus, also harbours six CBP genes; four of them with and two without an SLH domain, indicating that duplication and divergence of these porins occurred even before the evolution of chloroplasts. Prochlorococcus sp. CCMP1375 (SS120), a strain with one of the smallest genomes, contains only two CBP genes, but there is no simple relationship between genome size and the number of CBP genes. Inspection of the genomic neighbourhoods of these genes (Table S3, ESI $\dagger$ ) reveals that they are frequently localised in the vicinity of genes for the periplasmic binding proteins for $\mathrm{Zn}, \mathrm{Fe}$, or phosphate, or associated with genes suggesting a relationship with the metabolism of other metal ions, including $\mathrm{Mn}$, Co and Ni. Whilst analyses of genomic neighbourhoods, or regulation by a particular nutrient cannot directly infer function, we suggest that our demonstrated zincbinding ability of a CBP, and the high abundance of SYNW2224 under zinc-depleted conditions, adds two strong pieces of experimental evidence towards at least some of these porins playing an important role in the transport of essential metal ions such as zinc.

CBPs have previously been found to be up-regulated under nitrogen or sulfur starvation conditions in Synechococcus sp. PCC7942, ${ }^{102}$ and under phosphorus starvation in Synechococcus sp. WH8102 ${ }^{25,103,104}$ and Prochlorococcus spp. MED4 and MIT9313. ${ }^{105}$ This has led to suggestions that these proteins might increase the permeability of the outer membrane for enhanced nitrogen and sulfur uptake, ${ }^{102}$ or that they might transport phosphate. ${ }^{103}$ Cation- and anion-selective porins from the same organism, e.g. OmpF and PhoE from E. coli, share a high degree of similarity. Without direct biophysical studies, it is not possible to assign or predict particular selectivities for CBPs, but it may be expected that separate membrane channels for cationic and anionic nutrients should exist. ${ }^{106}$ If SYNW2224 proves to function in metal transport, then its increased expression under P-limitation ${ }^{25,103-105}$ could be an indirect consequence of the increased requirement for metaldependent alkaline phosphatases, which are also up-regulated under these conditions. ${ }^{103}$ The increased expression of these enzymes would likely also increase cellular demand for zinc and/or calcium. ${ }^{107,108}$ Upregulation of the definitively zincrelated metallothionein SmtA in response to P-limitation in Synechococcus sp. WH8102 has recently been observed, ${ }^{25}$ indicating that $\mathrm{Zn}$ and $\mathrm{P}$ metabolic processes are linked in this strain. A more general link between $\mathrm{Zn}$ and $\mathrm{P}$ metabolism is also reflected in global biogeochemical cycling. ${ }^{109}$

Regarding the transported species, for eukaryotic phytoplankton zinc uptake, the free ion concentration has been thought to determine bioavailability, ${ }^{51}$ but a recent study demonstrated that weak organic ligands in the presence of a much stronger ligand such as EDTA increased the rate of zinc uptake by zinc-limited cultures of Emiliania huxleyi and Thalassiosira weissflogii, via a mechanism that likely involves the formation of ternary complexes between the weak metal-ligand complexes and a cell surface uptake molecule. ${ }^{110}$ 


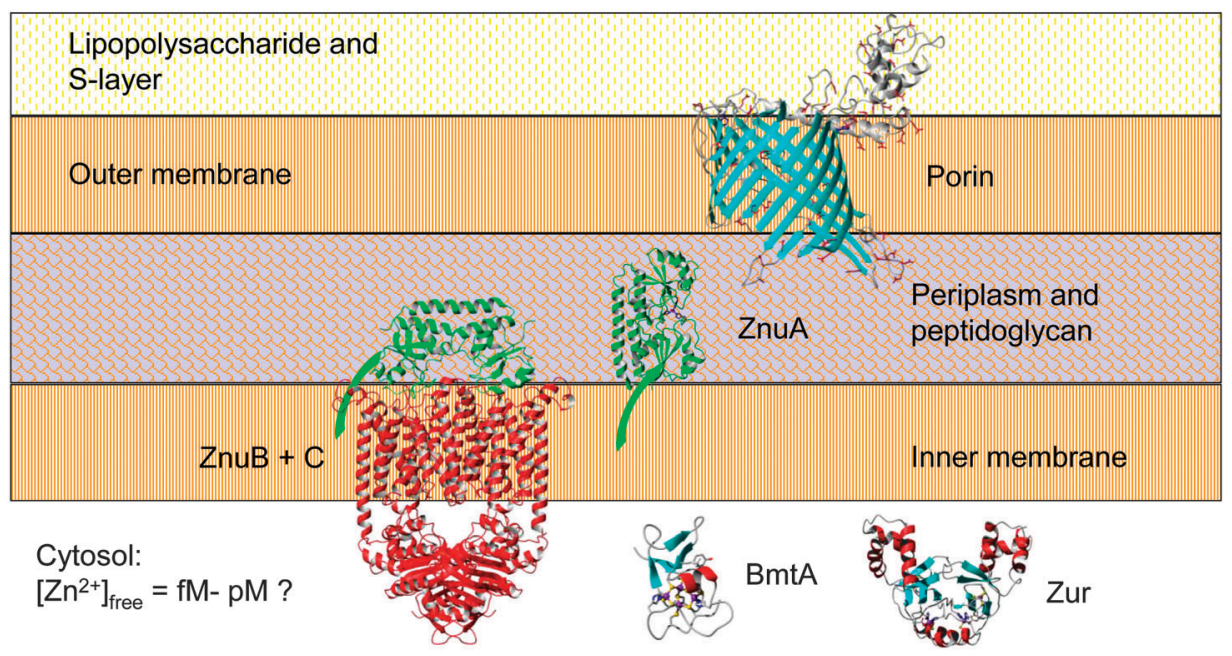

Fig. 6 Major components of the zinc uptake and retention system in Synechococcus sp. WH8102. The zinc uptake regulator Zur controls the transcription of the cytosolic bacterial metallothionein BmtA, as well as that of at least one ZnuABC zinc uptake transporter. Expression levels of the putative CBP (SYNW2224) are also zinc-dependent (this work). Note that Synechococcus sp. WH8102 likely utilises more than one porin and more than one ZnuABC transporter. In cyanobacteria, the S-layer is on the outside of the outer membrane; ${ }^{84,116}$ this would suggest that CBPs are oriented as shown. The extracellular S-layer homology domain of SYNW2224 may function in scavenging and adsorbing trace metal ions; this may subsequently enable passage through the porin into the periplasm. Eventually, mediated by the periplasmic binding protein ZnuA (illustrated with its membrane anchor), zinc is thought to pass through the inner membrane via one of its two ZnuABC systems. The bacterial metallothionein, predicted to be Zur-regulated, ${ }^{29}$ may provide an intracellular zinc reservoir.

Such a mechanism is also conceivable for zinc uptake by CBPs. SYNW2224 and SYNW2227 clearly have the ability to interact with partially complexed $\mathrm{Zn}^{2+}$, as presented by a nitrilotriacetic acid-based IMAC column. The conductance data characteristic of small solutes found for porins closely similar to SYNW2224 and SYNW2227 $7^{84}$ suggests that free $\mathrm{Zn}^{2+}$ (and likely other metal ions), or complexes with water, chloride, and other small anions, may be the entities transported, hence transport through the outer membrane could involve a decomplexation step.

The periplasm could then act as the first sorting point for different ions. Four periplasmic binding proteins were captured by Zn-IMAC, only two of them predicted to bind metal ions. Besides the periplasmic ZnuA component of a predicted zinc $\mathrm{ABC}$ transporter (SYNW2481), the $\mathrm{Fe}^{3+}$-binding protein FutA (SYNW1797) was also identified. The genome of Synechococcus sp. WH8102 contains an additional putative znuABC gene cluster (synw0969, 0970, and 0971) which according to RegPrecise ${ }^{101}$ harbours a predicted Zur recognition sequence in its promoter region. The periplasmic component of this cluster is synw0971; the respective protein was not detected in our metalloproteomics study.

The phosphate-binding protein PstS (SYNW1018) and the cyanate-binding protein CynA (SYNW2487) were also captured by Zn-IMAC. Whilst the observed metal affinity of PstS remains enigmatic, a very obvious metal-binding site ideally suited to bind $\mathrm{Zn}^{2+}$ (or related ions) was detected in CynA. Considering the scarcity of $\mathrm{Zn}^{2+}$ (and related ions such as $\mathrm{Co}^{2+}$ and $\mathrm{Cd}^{2+}$ ) in the natural habitat of Synechococcus sp. WH8102, it appears counter-intuitive that the bacterium should "waste" a potentially catalytically active metal ion for a merely supporting role in transport of an unusual nitrogen source. It is noteworthy that
Synechococcus sp. WH8102 is one of the few strains that contains an active uptake system for cyanate, ${ }^{111,112}$ and is also able to utilise cyanate as sole nitrogen source. ${ }^{113}$ Several Prochlorococcus strains also have this capability. Transcripts for cynA (likely most closely related to HLII types) were abundant in stratified surface waters of the Gulf of Aqaba. ${ }^{112}$ These waters are characterised by nitrogen depletion, but also by high Prochlorococcus abundance. It has been suggested that the ability to utilise an additional nitrogen source may give a competitive advantage in extremely $\mathrm{N}$-depleted surface layers of stratified ocean waters. It is intriguing that this may involve the participation of zinc or a closely related metal.

\section{Conclusions}

Our understanding of the mechanisms of zinc uptake into Gram-negative bacteria is incomplete, even though these are of particular interest for environments in which the concentration of essential zinc is extremely low, for example in oligotrophic oceans, but also during the acute phase response of a mammalian host to bacterial infection. ${ }^{114}$

This study has demonstrated the increased expression of a putative cyanobacterial porin (CBP) under conditions of zinc depletion, and its zinc-binding ability - a property not previously demonstrated for any bacterial porin. Together with bioinformatic evidence for likely regulation of CBP homologues by the zinc uptake regulator Zur, this suggests a role for at least some of these proteins in $\mathrm{Zn}^{2+}$ uptake across the outer membrane of cyanobacteria, although the transport of other 
inorganic cations is also likely. CBPs have previously been implicated in the uptake of carbon, nitrogen, and phosphorus. This work has shown that their expression may not only be regulated by lack of macronutrients, but also of micronutrients.

Furthermore, the isolation of a putative periplasmic zincbinding protein, $\mathrm{ZnuA}$, by $\mathrm{Zn}^{2+}$-IMAC has provided the first experimental evidence that this protein is expressed by Synechococcus sp. WH8102, and has the ability to bind zinc in vitro. Together with the finding that Synechococcus sp. WH8102 accumulates appreciable quantities of zinc even under extreme zinc depletion, and further bioinformatic information, this augments our understanding of zinc homeostasis in this and other marine cyanobacterial strains (Fig. 6). In addition, combining Zn-IMAC with comparative modelling has led to the discovery of a novel metal-binding site in the periplasmic cyanate-binding protein CynA that enables Synechococcus sp. WH8102 to exploit cyanate as nitrogen source.

Although no intact zinc-bound enzymes or other proteins were identified from any of the fractions analysed by native liquid chromatography, the alternative approach, IMAC, has enabled the enrichment of at least one protein involved in zinc uptake, as well as several candidates that warrant further detailed biophysical studies, including the porins SYNW2224 and 2227, the carboxysomal proteins CcmK1 and CcmK2, and the periplasmic cyanate binding protein CynA. It should be emphasised again that binding to a particular IMAC column does not allow any firm conclusions regarding any in vivo binding partners. It is possible that in several instances, the observed interaction with $\mathrm{Zn}^{2+}$ corresponds to adventitious binding. Careful inspection of each candidate, as a minimum via homology modelling and metal site analysis, should be carried out to eliminate false positives. Even then, caution must be applied regarding any statements pertaining to metal specificity, and further meta-data (such as genomic neighbourhood, synteny, and presence of transcription factor recognition sites) must be considered. Taking all these caveats into consideration, the experimental metalloproteomics in conjunction with bioinformatic approaches employed in the present work have uncovered expected and unexpected players in the zinc-binding network of a representative of an environmentally important class of marine phytoplankton.

\section{Acknowledgements}

This work was supported by the Leverhulme Trust (F/00 215/AY) and NERC (NE/F004249/1). Part of the equipment used in the research was obtained through Birmingham Science City with support from Advantage West Midlands and the European Regional Development Fund.

\section{References}

1 J. E. Coleman, Annu. Rev. Biochem., 1992, 61, 897-946.

2 C. Andreini, L. Banci, I. Bertini and A. Rosato, J. Proteome Res., 2006, 5, 3173-3178.

3 M. Brylinski and J. Skolnick, Proteins, 2011, 79, 735-751.
4 A. Cvetkovic, A. L. Menon, M. P. Thorgersen, J. W. Scott, F. L. Poole, F. E. Jenney, W. A. Lancaster, J. L. Praissman, S. Shanmukh, B. J. Vaccaro, S. A. Trauger, E. Kalisiak, J. V. Apon, G. Siuzdak, S. M. Yannone, J. A. Tainer and M. W. W. Adams, Nature, 2010, 466, 779-782.

5 J. P. Barnett, D. J. Scanlan and C. A. Blindauer, Anal. Bioanal. Chem., 2012, 402, 3311-3322.

6 S. M. Yannone, S. Hartung, A. L. Menon, M. W. Adams and J. A. Tainer, Curr. Opin. Biotechnol., 2012, 23, 89-95.

7 C. L. Dupont, A. Butcher, R. E. Valas, P. E. Bourne and G. Caetano-Anolles, Proc. Natl. Acad. Sci. U. S. A., 2010, 107, 10567-10572.

8 E. L. Mann and S. W. Chisholm, Limnol. Oceanogr., 2000, 45, 1067-1076.

9 P. W. Boyd, T. Jickells, C. S. Law, S. Blain, E. A. Boyle, K. O. Buesseler, K. H. Coale, J. J. Cullen, H. J. de Baar, M. Follows, M. Harvey, C. Lancelot, M. Levasseur, N. P. Owens, R. Pollard, R. B. Rivkin, J. Sarmiento, V. Schoemann, V. Smetacek, S. Takeda, A. Tsuda, S. Turner and A. J. Watson, Science, 2007, 315, 612-617.

10 M. Sinoir, E. C. V. Butler, A. R. Bowie, M. Mongin, P. N. Nesterenko and C. S. Hassler, Mar. Freshwater Res., 2012, 63, 644-657.

11 K. W. Bruland, Earth Planet. Sci. Lett., 1980, 47, 176-198.

12 J. R. Donat and K. W. Bruland, Mar. Chem., 1990, 28, 301-323.

13 R. W. Jakuba, M. A. Saito, J. W. Moffett and Y. Xu, Global Biogeochem. Cycles, 2012, 26, GB2015.

14 K. W. Bruland, Limnol. Oceanogr., 1989, 34, 269-285.

15 M. J. Ellwood and C. M. G. Van den Berg, Mar. Chem., 2000, 68, 295-306.

16 L. E. Brand, W. G. Sunda and R. R. L. Guillard, Limnol. Oceanogr., 1983, 28, 1182-1198.

17 W. G. Sunda and S. A. Huntsman, Limnol. Oceanogr., 1992, 37, 25-40.

18 K. G. Schulz, I. Zondervan, L. J. A. Gerringa, K. R. Timmermans, M. J. W. Veldhuis and U. Riebesell, Nature, 2004, 430, 673-676.

19 D. Malasarn, J. Kropat, S. I. Hsieh, G. Finazzi, D. Casero, J. A. Loo, M. Pellegrini, F. A. Wollman and S. S. Merchant, J. Biol. Chem., 2013, 288, 10672-10683.

20 F. M. M. Morel, J. R. Reinfelder, S. B. Roberts, C. P. Chamberlain, J. G. Lee and D. Yee, Nature, 1994, 369, 740-742.

21 J. H. Martin, Paleoceanography, 1990, 5, 1-13.

22 P. Flombaum, J. L. Gallegos, R. A. Gordillo, J. Rincón, L. L. Zabala, N. Jiao, D. M. Karl, W. K. W. Li, M. W. Lomas, D. Veneziano, C. S. Vera, J. A. Vrugt and A. C. Martiny, Proc. Natl. Acad. Sci. U. S. A., 2013, 110, 9824-9829.

23 W. G. Sunda and S. A. Huntsman, Limnol. Oceanogr., 1995, 40, 1404-1417.

24 M. A. Saito, J. W. Moffett, S. W. Chisholm and J. B. Waterbury, Limnol. Oceanogr., 2002, 47, 1629-1636.

25 A. Cox and M. Saito, Front. Microbiol., 2013, 4, 387.

26 J. S. Cavet, G. P. M. Borrelly and N. J. Robinson, FEMS Microbiol. Rev., 2003, 27, 165-181. 
27 M. Napolitano, M. A. Rubio, J. Santamaria-Gomez, E. OlmedoVerd, N. J. Robinson and I. Luque, J. Bacteriol., 2012, 194, 2426-2436.

28 C. A. Blindauer, Chem. Biodiversity, 2008, 5, 1990-2013.

29 J. P. Barnett, A. Millard, A. Z. Ksibe, D. J. Scanlan, R. Schmid and C. A. Blindauer, Front. Microbiol., 2012, 3, 142.

30 D. J. Scanlan, M. Ostrowski, S. Mazard, A. Dufresne, L. Garczarek, W. R. Hess, A. F. Post, M. Hagemann, I. Paulsen and F. Partensky, Microbiol. Mol. Biol. Rev., 2009, 73, 249-299.

31 B. Palenik, B. Brahamsha, F. W. Larimer, M. Land, L. Hauser, P. Chain, J. Lamerdin, W. Regala, E. E. Allen, J. McCarren, I. Paulsen, A. Dufresne, F. Partensky, E. A. Webb and J. Waterbury, Nature, 2003, 424, 1037-1042.

32 M. A. da Silva, A. Sussulini and M. A. Z. Arruda, Expert Rev. Proteomics, 2010, 7, 387-400.

33 W. Shi and M. R. Chance, Curr. Opin. Chem. Biol., 2011, 15, 144-148.

34 D. Fu and L. Finney, Expert Rev. Proteomics, 2014, 11, 13-19. 35 A. Sussulini and J. S. Becker, Metallomics, 2011, 3, 1271-1279.

36 S. Mounicou, J. Szpunar and R. Lobinski, Chem. Soc. Rev., 2009, 38, 1119-1138.

37 J. P. Barnett, D. J. Scanlan and C. A. Blindauer, Anal. Bioanal. Chem., 2012, 402, 3371-3377.

38 F. M. M. Morel, J. G. Rueter, D. M. Anderson and R. R. L. Guillard, J. Phycol., 1979, 15, 135-141.

39 N. M. Price, G. I. Harrison, J. G. Hering, R. J. Hudson, P. M. V. Nirel, B. Palenik and F. M. M. Morel, Biol. Oceanogr., 1989, 5-6, 443-461.

40 P. K. Smith, R. I. Krohn, G. T. Hermanson, A. K. Mallia, F. H. Gartner, M. D. Provenzano, E. K. Fujimoto, N. M. Goeke, B. J. Olson and D. C. Klenk, Anal. Biochem., 1985, 150, 76-85.

41 A. D. Gonzales, Y. K. Light, Z. Zhang, T. Iqbal, T. W. Lane and A. Martino, Can. J. Bot. Rev. Can. Bot., 2005, 83, 735-745.

42 U. K. Laemmli, Nature, 1970, 227, 680-685.

43 L. A. Kelley and M. J. E. Sternberg, Nat. Protoc., 2009, 4, 363-371.

44 B. X. Wei, A. M. Randich, M. Bhattacharyya-Pakrasi, H. B. Pakrasi and T. J. Smith, Biochemistry, 2007, 46, 8734-8743.

45 G. Minasov, Z. Wawrzak, A. Halavaty, L. Shuvalova, I. Dubrovska, J. Winsor, O. Kiryukhina, F. Bagnoli, F. Falugi, M. Bottomley, G. Grandi and W. F. Anderson, Protein Data Bank, 2011.

46 N. Koropatkin, A. M. Randich, M. Bhattacharyya-Pakrasi, H. B. Pakrasi and T. J. Smith, J. Biol. Chem., 2007, 282, 27468-27477.

47 J. Kern, R. Wilton, R. G. Zhang, T. A. Binkowski, A. Joachimiak and O. Schneewind, J. Biol. Chem., 2011, 286, 26042-26049.

48 N. G. Shuart, Y. Haitin, S. S. Camp, K. D. Black and W. N. Zagotta, Nat. Commun., 2011, 2, 457.

49 B. van den Berg, J. Biol. Chem., 2012, 287, 41044-41052.

50 R. Koradi, M. Billeter and K. Wuthrich, J. Mol. Graphics, 1996, 14, 51-55.
51 W. G. Sunda, Biol. Oceanogr., 1988, 6, 411-442.

52 W. G. Sunda, Front. Microbiol., 2012, 3, 204.

53 H. Irving and R. J. P. Williams, J. Chem. Soc., 1953, 3192-3210.

54 D. V. Tulumello and C. M. Deber, Biochim. Biophys. Acta, Biomembr., 2012, 1818, 1351-1358.

55 S. D. Smith, Y. M. She, E. A. Roberts and B. Sarkar, J. Proteome Res., 2004, 3, 834-840.

56 C. C. S. Kung, W. N. Huang, Y. C. Huang and K. C. Yeh, Proteomics, 2006, 6, 2746-2758.

57 C. L. Smith, J. L. Stauber, M. R. Wilson and D. F. Jolley, Anal. Bioanal. Chem., 2014, 406, 305-315.

58 A. H. Millar, Y. F. Tan, N. O'Toole and N. L. Taylor, Plant Physiol., 2010, 152, 747-761.

59 A. Galkin, Z. Li, L. Li, L. Kulakova, L. R. Pal, D. DunawayMariano and O. Herzberg, Biochemistry, 2009, 48, 3186-3196.

60 K. Nakahara, H. Yamamoto, C. Miyake and A. Yokota, Plant Cell Physiol., 2003, 44, 326-333.

61 A. Katayama, A. Tsujii, A. Wada, T. Nishino and A. Ishihama, Eur. J. Biochem., 2002, 269, 2403-2413.

62 A. M. Sevcenco, M. W. Pinkse, H. T. Wolterbeek, P. D. Verhaert, W. R. Hagen and P. L. Hagedoorn, Metallomics, 2011, 3, 1324-1330.

63 P. Asztalos, C. Parthier, R. Golbik, M. Kleinschmidt, G. Huebner, M. S. Weiss, R. Friedemann, G. Wille and K. Tittmann, Biochemistry, 2007, 46, 12037-12052.

64 K. Chandrasekhar, J. J. Wang, P. Arjunan, M. Sax, Y. H. Park, N. S. Nemeria, S. Kumaran, J. Y. Song, F. Jordan and W. Furey, J. Biol. Chem., 2013, 288, 15402-15417.

65 M. Babor, S. Gerzon, B. Raveh, V. Sobolev and M. Edelman, Proteins, 2008, 70, 208-217.

66 S. G. Kim, J. S. Chung, R. B. Sutton, J. S. Lee, L. LopezMaury, S. Y. Lee, F. J. Florencio, T. Lin, M. ZabetMoghaddam, M. J. Wood, K. Nayak, V. Madem, J. N. Tripathy, S. K. Kim and D. B. Knaff, Biochim. Biophys. Acta, 2012, 1824, 392-403.

67 L. C. Sieker, M. Holmes, I. Le Trong, S. Turley, M. Y. Liu, J. LeGall and R. E. Stenkamp, J. Biol. Inorg. Chem., 2000, 5, 505-513.

68 H. S. Gill and D. Eisenberg, Biochemistry, 2001, 40, 1903-1912. 69 Y. Zhang, Y. Feng, S. Chatterjee, S. Tuske, M. X. Ho, E. Arnold and R. H. Ebright, Science, 2012, 338, 1076-1080.

70 H. Sugawara, H. Yamamoto, N. Shibata, T. Inoue, S. Okada, C. Miyake, A. Yokota and Y. Kai, J. Biol. Chem., 1999, 274, 15655-15661.

71 S. Müller, K. Diederichs, J. Breed, R. Kissmehl, K. Hauser, H. Plattner and W. Welte, J. Mol. Biol., 2002, 315, 141-153.

72 J. J. Jeong, S. Fushinobu, S. Ito, B. S. Jeon, H. Shoun and T. Wakagi, FEBS Lett., 2003, 535, 200-204.

73 J. M. Berrisford, J. Akerboom, A. P. Turnbull, D. de Geus, S. E. Sedelnikova, I. Staton, C. W. McLeod, C. H. Verhees, J. van der Oost, D. W. Rice and P. J. Baker, J. Biol. Chem., 2003, 278, 33290-33297.

74 J. King-Scott, E. Nowak, E. Mylonas, S. Panjikar, M. Roessle, D. I. Svergun and P. A. Tucker, J. Biol. Chem., 2007, 282, 37717-37729. 
75 D. Takeshita and K. Tomita, Proc. Natl. Acad. Sci. U. S. A., 2010, 107, 15733-15738.

76 Y. Chen, R. K. Koripella, S. Sanyal and M. Selmer, FEBS J., 2010, 277, 3789-3803.

77 Y. Fan, L. Volkart, M. Gu, S. Axen, W. B. Greenleaf, C. Kerfeld and A. Joachimiak, Protein Data Bank, 2010.

78 Y. Tsai, M. R. Sawaya, G. C. Cannon, F. Cai, E. B. Williams, S. Heinhorst, C. A. Kerfeld and T. O. Yeates, PLoS Biol., 2007, 5, 1345-1354.

79 M. Takenoya, K. Nikolakakis and M. Sagermann, J. Bacteriol., 2010, 192, 6056-6063.

80 V. V. Bartsevich and H. B. Pakrasi, EMBO J., 1995, 14, 1845-1853.

81 N. M. Koropatkin, D. W. Koppenaal, H. B. Pakrasi and T. J. Smith, J. Biol. Chem., 2007, 282, 2606-2614.

82 H. Umeda, H. Aiba and T. Mizuno, Microbiology, 1996, 142, 2121-2128.

83 A. Hansel and M. H. Tadros, Curr. Microbiol., 1998, 36, 321-326.

84 E. Hoiczyk and A. Hansel, J. Bacteriol., 2000, 182, 1191-1199.

85 M. A. Saito, T. J. Goepfert and J. T. Ritt, Limnol. Oceanogr., 2008, 53, 276-290.

86 K. D. Krewulak and H. J. Vogel, Biochem. Cell Biol., 2011, 89, 87-97.

87 C. K. Lim, K. A. Hassan, A. Penesyan, J. E. Loper and I. T. Paulsen, Environ. Microbiol., 2013, 15, 702-715.

88 M. I. Hood, B. L. Mortensen, J. L. Moore, Y. F. Zhang, T. E. Kehl-Fie, N. Sugitani, W. J. Chazin, R. M. Caprioli and E. P. Skaar, PLoS Pathog., 2012, 8, e1003068.

89 M. Stork, M. P. Bos, I. Jongerius, N. de Kok, I. Schilders, V. E. Weynants, J. T. Poolman and J. Tommassen, PLoS Pathog., 2010, 6, e1000969.

90 R. R. Malmstrom, S. Rodrigue, K. H. Huang, L. Kelly, S. E. Kern, A. Thompson, S. Roggensack, P. M. Berube, M. R. Henn and S. W. Chisholm, ISME J., 2013, 7, 184-198.

91 E. A. Webb, J. W. Moffett and J. B. Waterbury, Appl. Environ. Microbiol., 2001, 67, 5444-5452.

92 A. R. Rivers, R. W. Jakuba and E. A. Webb, Environ. Microbiol., 2009, 11, 382-396.

93 M. C. Allievi, S. Florencia, P. A. Mariano, P. M. Mercedes, S. M. Ruzal and S. R. Carmen, J. Microbiol. Biotechnol., 2011, 21, 147-153.

94 L. Hudek, S. Rai, A. Michalczyk, L. C. Rai, B. A. Neilan and M. L. Ackland, BioMetals, 2012, 25, 893-903.

95 S. A. Craig, C. D. Carpenter, A. R. Mey, E. E. Wyckoff and S. M. Payne, J. Bacteriol., 2011, 193, 6505-6511.
96 T. H. Hohle, W. L. Franck, G. Stacey and M. R. O’Brian, Proc. Natl. Acad. Sci. U. S. A., 2011, 108, 15390-15395.

97 A. Speer, J. L. Rowland, M. Haeili, M. Niederweis and F. Wolschendorf, J. Bacteriol., 2013, 195, 5133-5140.

98 M. C. Conejo, I. Garcia, L. Martinez-Martinez, L. Picabea and A. Pascual, Antimicrob. Agents Chemother., 2003, 47, 2313-2315.

99 A. Nodop, D. Pietsch, R. Hocker, A. Becker, E. K. Pistorius, K. Forchhammer and K. P. Michel, Plant Physiol., 2008, 147, 747-763.

100 A. Hansel, F. Pattus, U. J. Jurgens and M. H. Tadros, Biochim. Biophys. Acta, Gene Struct. Expression, 1998, 1399, 31-39.

101 P. S. Novichkov, T. S. Brettin, E. S. Novichkova, P. S. Dehal, A. P. Arkin, I. Dubchak and D. A. Rodionov, Nucleic Acids Res., 2012, 40, W604-W608.

102 J. Sauer, U. Schreiber, R. Schmid, U. Volker and K. Forchhammer, Plant Physiol., 2001, 126, 233-243.

103 S. G. Tetu, B. Brahamsha, D. A. Johnson, V. Tai, K. Phillippy, B. Palenik and I. T. Paulsen, ISME J., 2009, 3, 835-849.

104 M. Ostrowski, S. Mazard, S. G. Tetu, K. Phillippy, A. Johnson, B. Palenik, I. T. Paulsen and D. J. Scanlan, ISME J., 2010, 4, 908-921.

105 A. C. Martiny, M. L. Coleman and S. W. Chisholm, Proc. Natl. Acad. Sci. U. S. A., 2006, 103, 12552-12557.

106 D. Duy, J. Soll and K. Philippar, Biol. Chem., 2007, 388, 879-889.

107 J. E. Coleman, Annu. Rev. Biophys. Biomol. Struct., 1992, 21, 441-483.

108 S. Kathuria and A. C. Martiny, Environ. Microbiol., 2011, 13, 74-83.

109 R. W. Jakuba, J. W. Moffett and S. T. Dyhrman, Global Biogeochem. Cycles, 2008, 22, GB4012.

110 L. Aristilde, Y. Xu and F. M. M. Morel, Environ. Sci. Technol., 2012, 46, 5438-5445.

111 G. S. Espie, F. Jalali, T. Tong, N. J. Zacal and A. K. C. So, J. Bacteriol., 2007, 189, 1013-1024.

112 N. A. Kamennaya, M. Chernihovsky and A. F. Post, Limnol. Oceanogr., 2008, 53, 2485-2494.

113 Z. C. Su, F. L. Mao, P. Dam, H. W. Wu, V. Olman, I. T. Paulsen, B. Palenik and Y. Xu, Nucleic Acids Res., 2006, 34, 1050-1065.

114 E. K. LeGrand and J. Alcock, Q. Rev. Biol., 2012, 87, 3-18.

115 F. R. Tabita, S. Satagopan, T. E. Hanson, N. E. Kreel and S. S. Scott, J. Exp. Bot., 2008, 59, 1515-1524.

116 J. Šmarda, D. Šmajs, J. Komrska and V. Krzyžánek, Micron, 2002, 33, 257-277. 